\title{
Perspective on Curved Surfaces in the Age of Pozzo: The Nuova Pratica di Prospettiva of Paolo Amato
}

\author{
Fabrizio Agnello1
}

Published online: 9 May 2016

(C) Kim Williams Books, Turin 2016

\begin{abstract}
The study focuses an almost unknown treatise on perspective, The Nuova Pratica di Prospettiva, written by the priest Paolo Amato (1634-1714) in the last years of his life and published posthumously in 1733. The main points of interest of the Nuova Pratica is the perspective projection on cylindrical surfaces, which exceeds the coeval 'practical' treatises on perspective. A detailed resume of Amato's treatise is accompanied by geometric schemes illustrating the perspective method proposed by the author. None of the paintings made by Amato has come down to us, but the vault covering a hall added to a Norman church in Palermo shows a trompe l'oeil that was painted by one of his favorite disciples. A repeatable method, integrating laser scanning and photogrammetric surveying with digital representation tools, supported the restitution of the painted architectural scene and highlighted potential links to the content of the treatise. The geometric analysis of the orthogonal projection of the vault highlighted a rigorous and unexpected geometric scheme underlying the trompe l'oeil.
\end{abstract}

\section{Introduction}

By the age of Amato, many treatises on perspective had discussed perspective on curved surfaces; the painted vaults in churches and palaces evidence the skill of painters in dealing with such problems. Treatises provided effective rules for the construction of perspectives on flat surfaces but, when dealing with curved surfaces, they abandoned rules and proposed practical solutions.

Fabrizio Agnello

fabrizio.agnello@unipa.it

1 Department of Architecture, University of Palermo, Via Isidoro La Lumia 36, 90139 Palermo, Italy 
The studies on trompe l'oeil, which flourished in the past century, have widely dealt with perspective paintings on flat surfaces, often using modern surveying techniques (photogrammetry, topography) to produce rectified images or orthophotos supporting the analysis of the projective layout (vanishing points, position of the point of view, etc.). Such studies usually aim to analyse the features of the painted architecture (proportions, styles) and sometimes propose the virtual combination of the real space (the hall, the nave) and the illusory scene. The studies on perspectives on vaults and domes are rare; scholars deal in this subject with more uncertainty, both for the lack of a 'scientific' background from treatises and for the difficulty of performing geometrical analyses in a $3 \mathrm{D}$ context. ${ }^{1}$

The recent evolution of digital tools for $3 \mathrm{D}$ surveying and modeling allows the generation of accurate 3D texturized models of real scenes. CAD software allows today the visualization and inspection of such models (measuring, sectioning), thus enabling an accurate 3D analysis of paintings on curved surfaces.

This study aims to discuss an almost unknown treatise, published in Sicily in the first half of the eighteenth century, where a scientific approach to the drawing of perspective on curved surfaces is proposed. A detailed overview of the treatise means to make justice of a work that stands comparison to other famous treatises of its age.

Unfortunately, none of the paintings made by the author has come down to us, but the vault covering a hall added to a Norman church in Palermo shows a trompe l'oeil that was painted by one of his favorite disciples. This vault therefore represents the only surviving model that may have adopted the scientific approach proposed in the treatise. The geometric analysis of the painted vault, executed by means of 3D survey and modeling, means to highlight potential links to the content of the treatise of Amato.

\section{The Nuova Pratica di Prospettiva}

Paolo Amato (1634-1714) wrote the Nuova Pratica di Prospettiva in the last years of his life; he meant to divide the treatise into two volumes, respectively dedicated to optics and practical perspective and to catoptrics and dioptrics. At his death, he left an incomplete manuscript of the first book; this manuscript was edited by Giuseppe Gentile, an abbey of the congregation of the charity of Saint Peter, and was published in 1733 .

The published edition ${ }^{2}$ opens with an introduction by the editor, which outlines the biography and the work of the author. Born in Ciminna, a small town near Palermo, in Sicily, Amato moved at a young age to Palermo and became a priest in the religious order of 'Crociferi'. His talent in drawing oriented his education to geometry, optics and catoptrics. In 1686 the 'Senatus' of Palermo appointed him as

\footnotetext{
1 In 1999 Daniele Di Marzio published an interesting study where a real model of a hall was used to simulate the projection on a vault with practical methods (Di Marzio 1999, pp. 153-177).

2 The original volume of the treatise is registered as rari.sic.627 at the Biblioteca centrale della Regione Sicilia "A. Bombace" in Palermo. Publication has been generously granted by the Assessorato Regionale dei Beni Culturali e dell'Identità Siciliana, Dipartimento dei Beni Culturali e dell’ Identità Siciliana.
} 
Fig. 1 Amato's perspective drawing of a scenography for a religious ceremony in the Cathedral of Palermo in 1691 (Ruggeri Tricoli 1983, p. 56)

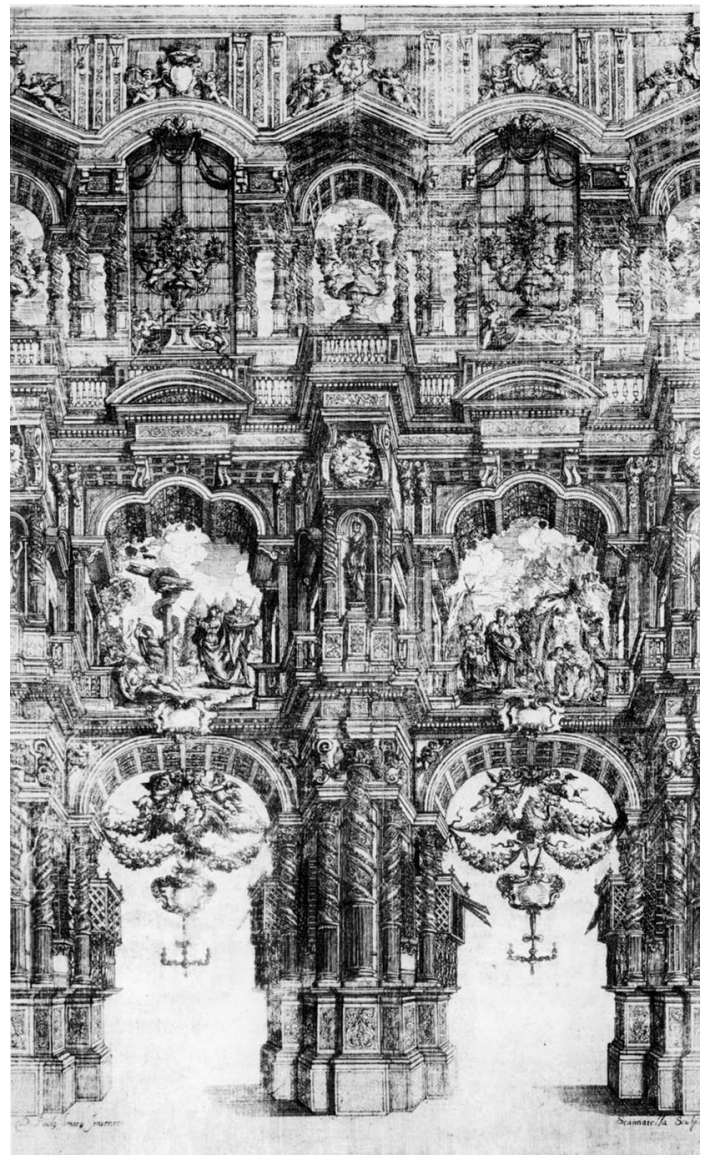

Chief Architect and charged him for the design of ephemeral sceneries for religious feasts or relevant ceremonies (e.g. noblemen's funeral). The drawings illustrating such sceneries evidence a full acquaintance with perspective representation (Fig. 1). In the treatise Amato claims that he has painted some vaults in noble palaces and a temporary ceiling inside the cathedral of Palermo; unfortunately none of these works has come down to us.

The title of the treatise-La nuova Pratica di Prospettiva. Nella quale si spiegano alcune nuove opinioni, e la Regola universale di disegnare in qualunque superficie qualsivoglia oggetto. Opera utile, e necessaria a Pittori, Architetti, Scultori, e Professori di Disegno (The New Practice of Perspective. In which some new opinions, and the universal rule to draw any object on any surface, are explained. A work that is useful and necessary to painters, architects, sculptors, and professors of drawing) — claims the novelty of the proposed method, which provides for the first time a rule (not practical artifices) to draw any object on any surface. The term 'practice' echoes the titles of many other treatises on perspective; using the adjective 'practical', the authors meant to point out that their treatises were 
addressed to painters and architects and that they differed from the mathematic treatises on perspective. ${ }^{3}$

The structure of Amato's treatise shows its educational purpose: a long Preface (pp. 1-12) introduces the reader to the subject; the First Part (pp. 13-27) provides the basics of geometric drawing and orthographic projection. The Treatise on Optics (pp. 28-41), discusses the general principles of perspective projection and introduces the Nuova Pratica (pp. 42-85). The Nuova Pratica was incomplete at the death of the author; the third part was almost finished, whereas the fourth one was missing. The Nuova Pratica illustrates the perspective method proposed by Amato and, as a further evidence of his educational intentions, proposes a sequence of subjects with an increasing degree of complexity. Thirty-five plates, illustrating the discussed subjects, close the volume. In the last page of the published edition, the editor inserts a note to inform the reader that he worked on an incomplete manuscript and that none of the drawings referred to in the text had come to him. He declares that he is the author of the plates and that he inferred their content from the text; finally, he charges on himself the responsibility for potential errors. ${ }^{4}$

\section{The Preface}

The Preface is divided into two chapters: the first one introduces the reader to the subject of the treatise, and the second one outlines a history of perspective. In the first chapter, Amato states that his treatise means to offer a 'practical' approach to perspective and that the Treatise on Optics must be considered nothing more than a premise to the discussion on perspective. In the conclusion of the chapter, the author refers to the opinions on perspective by Leonardo, Alberti, Lomazzo, Serlio, Vignola, Viola and Caramuel. ${ }^{5}$ In the second chapter, introducing a detailed overview of treatises on perspective, Amato states:

All these authors, and others in recent times, plus other ones that I do not know, are worth our praise for having improved the rules of perspective and having produced magnificent drawings. ... Most of them discussed the ordinary rule for perspective, i.e. to draw objects placed behind the picture plane, with the projection axis orthogonal to such plane; some of them have discussed the problem of drawing the perspective on the curved surfaces of

\footnotetext{
3 The adjective practical appears, presumably for the first time, in 1545 in Le due regole della prospettiva pratica of Vignola; a few years later it is inserted in the titles of the treatises of Barbaro (1568) and, at the end of the century, of Sirigatti (1596). After the publication of the treatise of Guidobaldo del Monte (1600), the adjective appears more frequently; as an example we can recall the treatises of Cigoli (1613), Pietro D'Accolti (1625), Du Breil (1642), Migon (1643) and Contino (1645). The birth and development of the distinction between scientific and practical perspective is acutely resumed in Vagnetti (1979, pp. 296-307).

4 "Mancano altri esempi per compimento di questa sezione; e manca ancora la Sezione quarta... Si prega ancora il Lettore a compatire gli errori, che troverà nelle figure... poiché essendo restata imperfetta l'Opera, ed essendosi smarrite le figure originali dell'Autore, si è cercato, nella miglior maniera, ch'è stato possibile, cavarle dallo scritto" (Amato 1733, p. 85).

5 Some personal notes attest that Paolo Amato possessed the copy of the treatise of Caramuel currently registered at the Regional Library in Palermo (Ruggeri Tricoli 1983, p. 18).
} 
vaults and domes; but they have not provided a universal method to draw such perspectives... some others have kept the rule unrevealed. [Tutti questi, e altri Autori più moderni, ò altri, che non mi sono arrivati alla notizia, sono degni d'eterna lode... La maggior parte di essi si sono diffusi sulla regola ordinaria, di mettere in operazione di Prospettiva gli oggetti posti di dietro la superficie, $e$ che l'asse del cono visuale formi in essa superficie angoli retti; e benché alcuni di essi avessero toccato il modo d'operare in alcune figure piane, che unite formano angoli; e ancora nelle superficie concave delle volte, e cupole; non si sono però dilatati in mostrare il metodo con una regola universale di disegnarle in Prospettiva... Altri hanno passato sotto silenzio la regola.] (Amato 1733, p. 8).

Amato claims that his universal method overcomes the restrictions of the ordinary rule; his wide erudition led him to state that the previous treatises on perspective had not adequately discussed the perspective on curved surfaces; nonetheless, he supposes that the quoted authors (or some of them) were well aware of a proper solution, and that they preferred to keep it unrevealed.

The projection on curved surfaces is obviously useful when depicting a perspective on vaults; that's why, in the Preface and through the whole treatise, Amato harshly criticizes the 'practical' methods proposed in other treatises:

Some of them start the operation in a correct way, but soon after they use a purely practical method, suggesting the use of grids, dotted papers, candles, cords and other instruments that are not effective ... the authors ... have not discussed such problems, preferring a mere practical approach. [Diversi cominciano d'un forte l'operazione, e sieguono con un altro metodo di mera Prattica, volendo, che si operi con craticole, carte ponteggiate, lumi, fili, strumenti, e altri, li quali per lo più possono essere fallaci... gli Artefici non l'hanno... perfezionata... stimando d'operare più facilmente, e giustamente con la mera prattica.] (Amato 1733, p. 8).

To confirm this statement, Amato reports several selected passages from treatises discussing the projection on curved surfaces. He arranges the 'practical' artifices in two groups: (a) projection with cords; (b) projection of shades with a candle.

Referring to the projection with cords, Amato quotes a passage from the treatise of Pietro D'Accolti: the author suggests fixing a cord to the top of the dome and, after placing an eye to this line, ordering someone else to mark on the vault the points that the cord hides. ${ }^{6}$ He then quotes a passage from La Perspective Curieuse, where Niceron proposes two methods to project a 'plumb line' on a vault: in the first one, echoing D'Accolti, he suggests placing the eye on the point of view and marking the hidden points on the vault with a pole having a charcoal at one end; in

\footnotetext{
${ }^{6}$ The quotation of D'Accolti is correct, but not complete. Actually, D'Accolti declares to be aware of the difficulty implied in the suggested method, and proposes a quite complex and not exact solution for the perspective projection on double curved surfaces (D'Accolti 1625, p. 52).
} 
the second method, Niceron suggests putting a candle in the point of view and marking the shade projected on the vault by the cord. ${ }^{7}$

Referring to the use of grids and candles, Amato quotes the last chapter of Pozzo's Perspectiva Pictorum, where the well-known method of the 'three grids' is discussed: "(Pozzo) states that for the vaults we have to make three grids: the first one is overlaid to the perspective drawing; the second one must be made of threads in the air; if we place a candle on the point of view, the shadows will produce the third grid on the vault" (Amato 1733, p. 10). The treatise of Andrea Pozzo, universally reputed one of the best at his age, does not discuss any of the problems proposed by Amato; we must notice that the Perspectiva Pictorum was published when Amato was still writing his treatise. Amato shows no awe before the famous painter and his grids, which are criticised as 'practical' methods.

The list of authors proposing practical artifices for the perspective on curved surfaces includes Giulio Troili, Gaspard Schott, Bernard Lamy and Claudio Francesco Milliet Deschales. The quoted passage from the Seu cursus mathematicus anticipates one of the peculiar features of the Nuova Pratica, i.e. the construction of a perspective without vanishing points. Amato translates the passage literally:

It often happens that the picture plane is not flat, but circular or elliptical, or it is made of many flat, curved or irregular surfaces; then, it is very hard, and often impossible, to detect the principal point, the horizon line and the distance point; in these circumstances we have to refer to an universal practice. [Sape accidit ut tabella plana non sit, sed constet superficie circulari, Ellyptica, ut alia quavis, immo saepe constet ex pluribus superficiebus planis, aut curvis, ita tamen irregularibus, ut operosum sit, \& sape impossibile punctum principale, lineam horizontalem, puncta distantiae assignare, unde ad praxin universalissimam recurrendum est.] (Milliet Dechales 1674, p. 519).

The Nuova Pratica can be considered as a reply to Milliet Dechales, because Amato proposes a rule that substitutes for universal practice, when dealing with projection on curved surfaces. In the Preface Amato shows his wide erudition and evidences his confidence with the mentioned treatises, but oddly he does not mention the works of Girard Desargues and Abraham Bosse. The lack of specific studies on Amato's education allows no arguing on the matter; nonetheless, we can argue that Amato would have blamed as 'practical' approaches the solutions for the projection on vaults with candles, illustrated by Bosse's magnificent drawings. Closing the Preface, Amato states the mentioned authors, when discussing the perspective on vaults, substitute rules for practical artifices. ${ }^{8}$ He finally claims his

\footnotetext{
7 "Encore que le méthode universelle de cette proposition suffise pour faire toutes fortes de Perspectives sur toutes fortes de surfaces je veux ajouter qu'il y a des peintres qui tenant l'œil ferme dans un même point prennent une perche, au bout de laquelle ils attachent du charbon dont ils crayonnent les premières \& les plus grossiers traits de l'image qu'il veulent mettre en Perspective: \& que d'autres usent la nuit d'une lampe qui tient le lieu de l'œil, \& qui envoyé les ombres de chaque partie de l'objet à la voute, sur laquelle, suivant les ombres, le peintre tire les traits..." (Niceron 1652, p. 128).

${ }^{8}$ For a detailed description of the projection on curved surfaces with cords, see Di Marzio (1999).
} 
method is universal, no matter the complexity of objects nor the shape of the picture surface or the position of the object.

\section{The First Part}

The Preface is followed by the First Part (pp. 13-27, plates 1-10), which provides the basics of drawing and some principles of geometry useful in the practice of perspective. The First Part is divided into seven chapters: the first chapter reports some geometrical definitions; the second one is dedicated to well-known geometric constructions; the third chapter discusses the definition of solids, while the following chapters are dedicated to top, frontal and profile orthographic projection, useful in the method proposed by the author.

\section{The Treatise on Optics}

The Treatise on Optics (pp. 28-41, plates 11-13), divided into four chapters, introduces the Nuova Pratica. The first chapter has no point of interest, since the author superficially mentions several treatises on optics; in the second chapter, outlining the graphic scheme that he will use in the Nuova Pratica, Amato introduces the Cartone, that is the sheet where perspective is drawn. He states that the Cartone has to equal the surface where the perspective will be painted. Anticipating the main point of interest of the Nuova Pratica, Amato states that, if the surface is curved, the Cartone must be equivalent to the unrolled surface; laying the Cartone on the surface, the perspective drawing is impressed with riddles.

The third chapter of optics discusses the projection of objects standing across or in front of the picture surface. Amato states that placing the objects behind the picture surface is a habit that has become a rule, whereas the objects can stand elsewhere: the ones that stand on the picture surface preserve their form and size ${ }^{10}$ while the ones that stand in front of the picture surface are magnified. ${ }^{11}$ The fourth and final chapter of the Treatise on Optics discusses the setting of the proper distance between the point of view and the picture surface, with reference to the size of the object.

\footnotetext{
9 La Carta composta d'alcuni fogli uniti, della quale li Pittori si servono ordinariamente, che chiamano cartone, dove si ha da disegnare l'Opera posta in Prospettiva, deve essere larga, e alta, per quanto sarà la superficie della Parete, Tela Tavola o altro, dove si doverà dipingere l'Opera; quale se sarà piana, o angolare, o circolare, o mista; come ancora, se sarà perpendicolare, o inclinata, o declinata, o parallela all'orizzonte, o di qualsivoglia forma, sempre si dovrà ridurre in una superficie piana... Quale cartone, finita l'operazione, si usa di punteggiarlo, o perfilarlo, per imprimerlo nella detta superficie della Parete (Amato 1733, p. 34).

${ }^{10}$ In tanto dico, che non è cosa essenziale, che nel disegnare gli oggetti in prattica di Prospettiva habbiano ad essere posti dietro la superficie della Parete, per essere secati, in essa dalli raggi visuali, che verranno scortati, e degradati; essendo che si possono ancora dipingere l'istessi, ò altri oggetti, così quelli, che saranno nell'istessa superficie, che non degradano, come gli altri oggetti, che sportano fuori di essa. Questi, improntati o terminati in essa superficie non solamente non degradano dal suo essere, ma si anderanno dilatando, e verranno nella Parete più grandi (Amato 1733, p. 36).

11 It must be noticed that the perspective of objects standing between the picture surface and the center of projection can be drawn only if the object does not intersect the visual plane that is parallel to the picture plane.
} 


\section{The Nuova Pratica}

The Nuova Pratica (pp. 42-85, plates 14-35) is divided, as mentioned above, into three sections, respectively dedicated to the projection of plane figures, of solids and of objects crossing (or placed in front of) the picture surface.

The drawings referred to in the first chapter illustrate the perspective of geometric figures on: (a) a vertical picture plane (plates 14-16); (b) a slanting picture plane (plates 17 and 18); (c) a couple of vertical self-intersecting picture planes (plates 19 and 20); (d) cylindrical surfaces (plates 21 and 22).

The drawings illustrating the second chapter, dealing with the perspective of solids, follow the same sequence: (a) (plates 23 and 24); (b) (plate 25); (c) (plate 28), (d) (plates 29 and 30). Plates 26 and 27 illustrate the perspective on a horizontal picture plane.

Plate 31 shows an approximate method for the projection on domes, which echoes the solution proposed by Caramuel and its lack of accuracy as well.

Plates 32-35 illustrate the chapters of the third section, where the projection of geometric figures placed across (or in front of) the projection surface is discussed.

The perspective method proposed in the Nuova Pratica is nothing but Brunelleschi's 'legitimate construction'. ${ }^{12}$ It is well known that this perspective method does not use vanishing points: the perspective image of a point is given by the coordinates of the point where the visual ray intersects the picture plane. Amato was obviously aware of the developments of perspective in the Modern Age, and the use of a vanishing point in plate 18 evidences his confidence with the subject. Nonetheless, Amato prefers using the 'legitimate construction' along the whole treatise, because he is aware that the novelty in his treatise is the perspective on curved picture surfaces.

In most drawings referring to the 'legitimate construction', a horizontal straight line divides the plate into two strips: the upper part usually shows a profile view and the lower one a top view. Both views report the position of the point of view $(\mathrm{PoV})$, the vertical picture plane and the object behind it. A vertical straight line spanning the height of the paper represents the baseline of the vertical picture plane in top view and its vertical section in profile view. From the point of view, a straight line perpendicular to the picture plane detects in both views the position of the 'central' vanishing point $(\mathrm{CvP})$, i.e. the point of concurrence of lines that are orthogonal to the picture plane.

The perspective of a point, say ' $\mathrm{P}$ ', is drawn as follows: in top and profile views straight lines from $P o V$ to the point 'P' (visual rays) intersect the vertical line representing the picture plane; the $x$ coordinate of the intersection point in top view measures the distance from the $C v P$, whereas the $y$ coordinate measures the distance from the ground line in profile view. The coordinates are reported on the sides of a rectangle framing the perspective; the intersection of the vertical line through the $x$ coordinate and the horizontal line through the $y$ coordinate is the perspective of the point 'P' (Fig. 2). Sometimes the lines concurring to the 'central' vanishing point substitute for $x$ coordinates (Fig. 3).

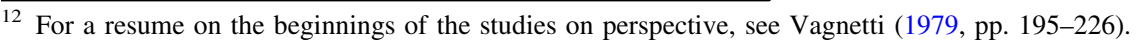




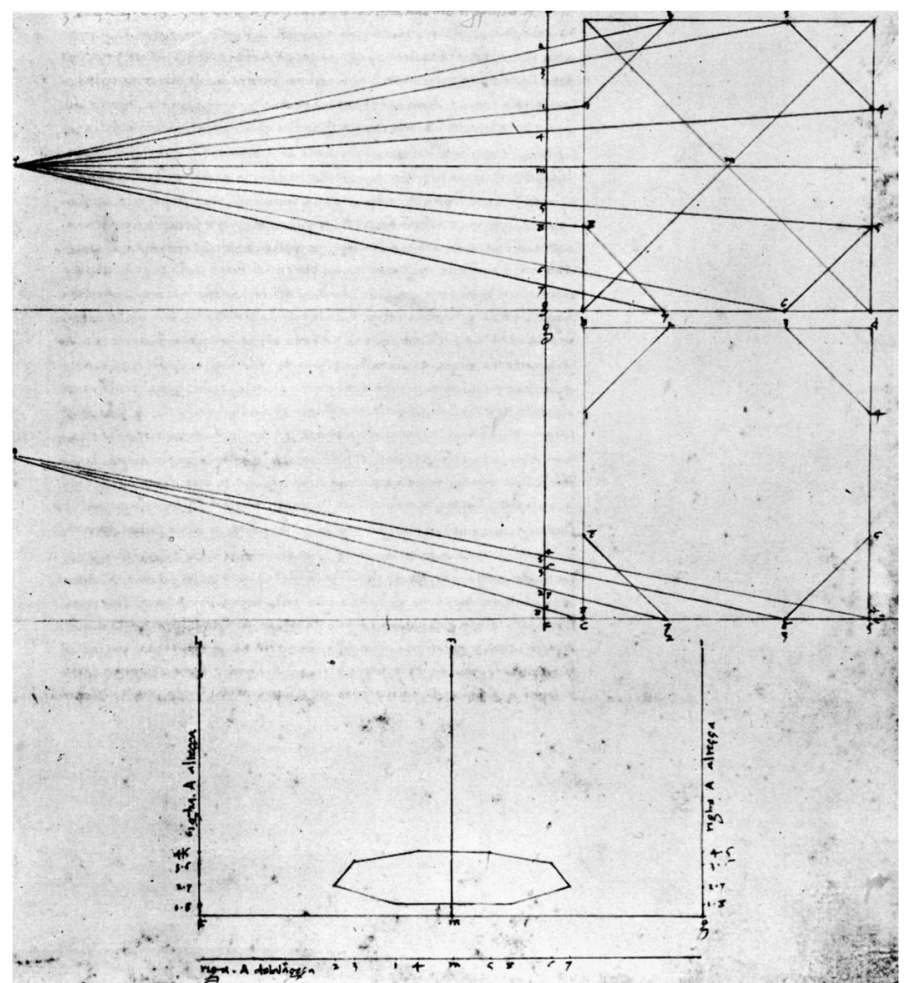

Fig. 2 The 'legitimate construction' in Piero della Francesca De Prospectiva Pingendi (Della Francesca 1984, Tav. XXII). In this drawing, top view is set above the profile view

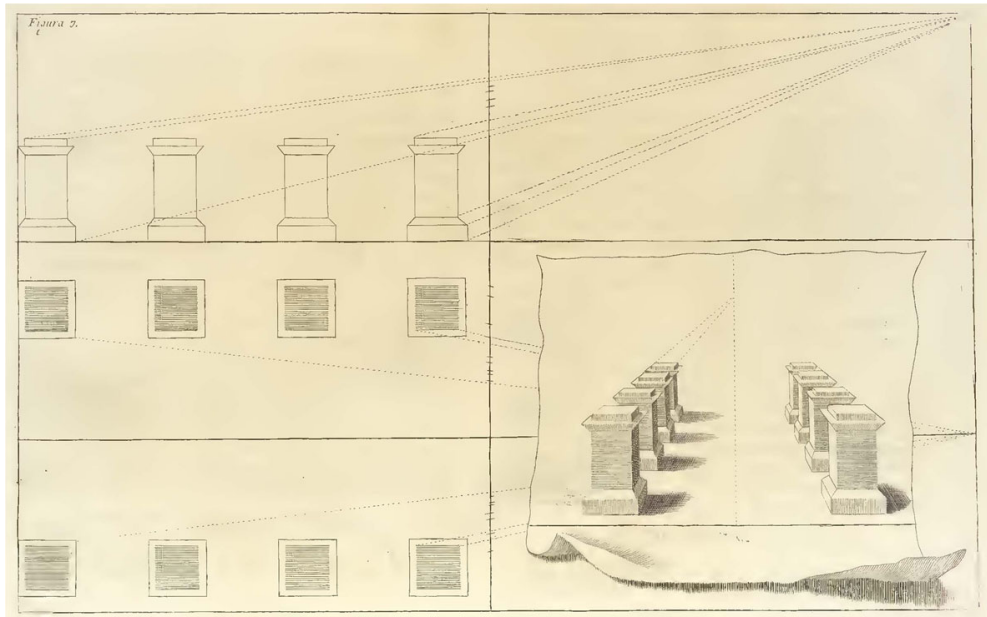

Fig. 3 The 'legitimate construction' in Andrea Pozzo Perspectiva pictorum et architectorum (Pozzo 1693, vol. II) (Fig. 9) 
In Amato's treatise the conventional layout of the 'legitimate construction' is used in perspectives on vertical picture planes, namely in plates 14-16 and 23 (Fig. 4); in the remaining plates he keeps the same layout, but the process leading to the perspective of points is adjusted keeping into account the orientation or the shape of the picture surface. In the plates the Cartone is represented as a rectangle framing the perspective drawing. The baseline of the Cartone is the $X$ axis, whereas its vertical axis of symmetry is the $Y$ axis (Fig. 5).

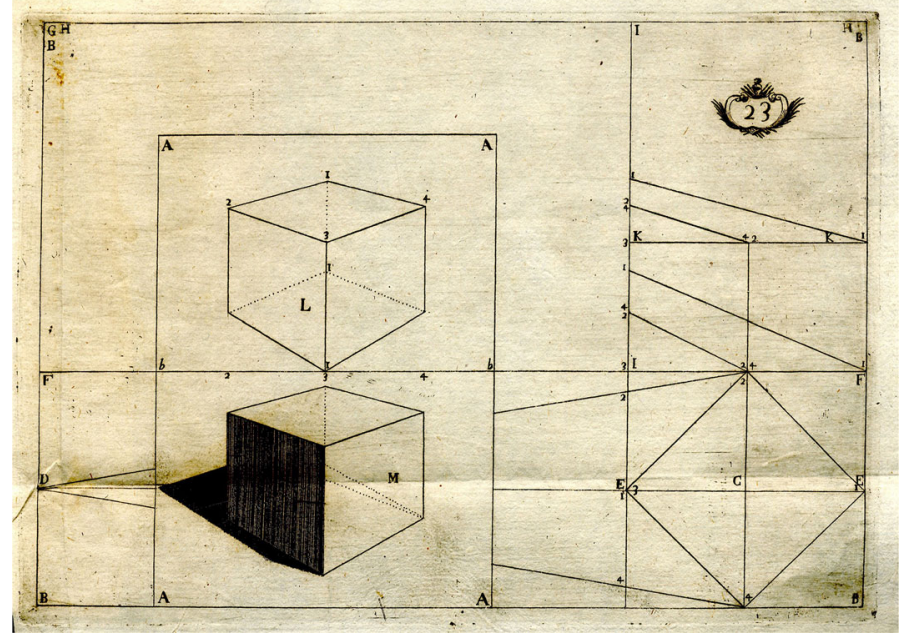

Fig. 4 Nuova Pratica di Prospettiva, plate 23: perspective of a cube onto a vertical plane

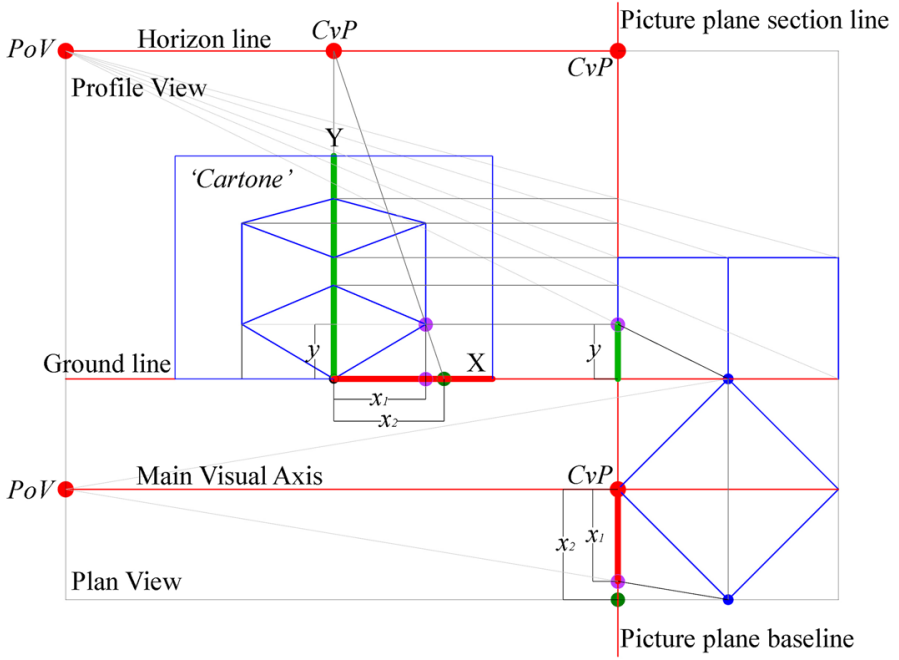

Fig. 5 Geometric scheme of the 'legitimate construction' from plate 23, and classification of its elements 
The treatise of Paolo Amato is almost unknown to scholars; that's why the description of its content has been developed so far by pedantically reporting the sequence of chapters and subjects. The discussion will now focus on two specific problems that show at its best the novelty of the treatise: the perspective on a slanting picture plane and the perspective on a cylindrical picture surface.

\section{Perspective on Slanting Picture Planes (Plates 17, 18 and 25)}

Plates 17 and 18 show two different solutions for the projection of a pentagon on a slanting picture plane. Plate 17 is one exception in the treatise of Amato, since it is the only plate where lines concurring to a vanishing point substitute for $x$ coordinates (Fig. 6).

The vanishing point appearing in plate 17 is not the 'usual' central vanishing point, because the lines perpendicular to the baseline of the picture plane in top view are 'not' perpendicular to the slanting picture plane. The drawing of the Cartone evidences such occurrence; in profile view its upper edge overlays the horizontal line from the $P o V$; the height of the Cartone equals the length of the picture plane in profile view and thus the Cartone extends downward the ground line. In the proposed scheme (Fig. 7), the baseline of the Cartone overlays the ground line and its upper edge moves upward the horizontal line from the PoV. Amato is aware of such occurrence:

When drawing the perspective of objects on slanting planes... we cannot use the rule, according to the general and usual method, as it is proposed when the picture plane is vertical and in front of the eye... we will draw the Cartone of the slanting wall by reporting its sizes... the point of view, ... placed in front of the eye, now we see it higher than the eye, since the surface slants [Dovendosi disegnare gli oggetti in Prospettiva nelle superfici inclinate... non si può dare la Regola, che sia secondo il metodo generale \& ordinario, come si dona assentata nelle superfici che stanno perpendicolari \& in fronte

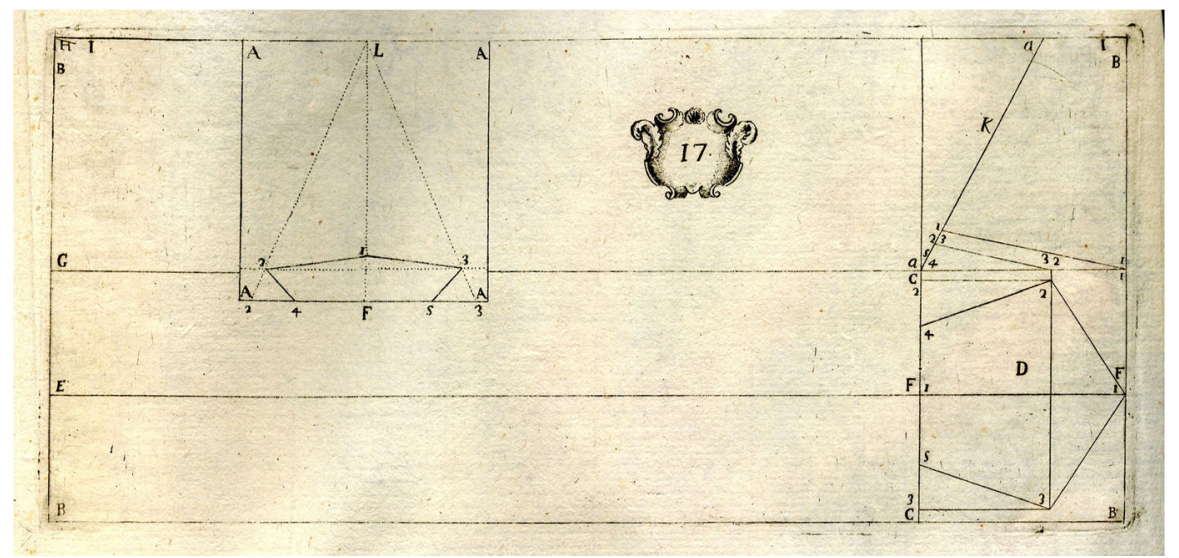

Fig. 6 Nuova Pratica di Prospettiva, plate 17: 'legitimate construction' with a vanishing point of a pentagon projected onto a slanting plane 


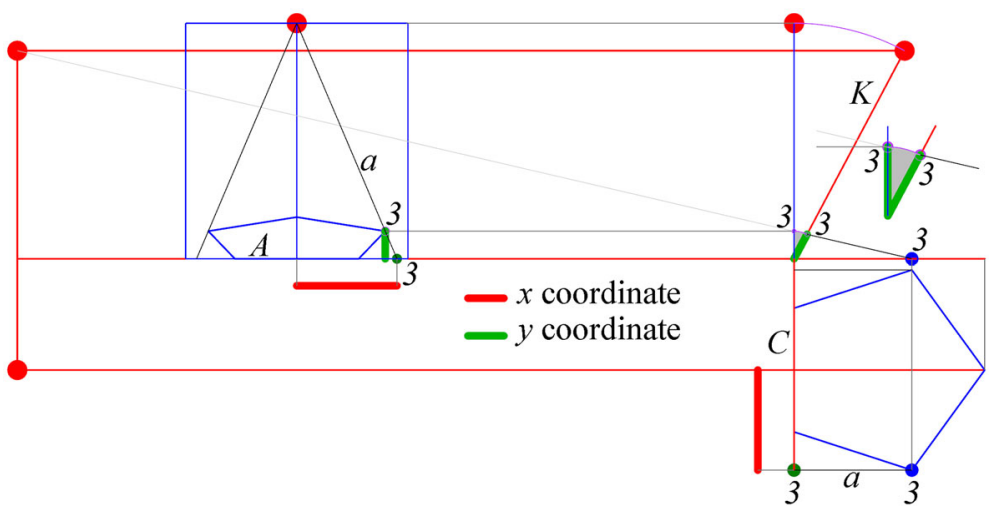

Fig. 7 Geometric scheme from plate 17

all'occhio... formeremo il Cartone della parete inclinata, per quanto sarà la sua larghezza e altezza... il punto della veduta, segnato con la lettera L, posto in fronte all'occhio, quale benché ora si vede più alto dell'occhio, quando la detta superficie si inclinerà a suo luogo] (Amato 1733, p. 49).

The content of plate 17 is correct, but we can argue that the proposed layout (see Fig. 7) illustrates the literal content of the text. The perspective image of a line 'a', concurring to the vanishing point, is determined as follows: (a) in top view line ' $a$ ' starts from the vertex ' 3 ' of the pentagon and intersects at right angle the baseline ' $\mathrm{C}$ ' of the picture plane; (b) the point ' 3 ' on the baseline ' $\mathrm{A}$ ' of the Cartone, measures the $x$ coordinate of the intersection point; (c) the perspective image of the line ' $a$ ' connects point ' 3 ' on the line ' $A$ ' to the vanishing point. The y coordinate of the perspective image of point ' 3 ' is measured in profile view: (d) a visual ray from ' 3 ' intersects the slanting profile ' $\mathrm{K}$ ' of the picture plane in point ' 3 '; (e) point ' 3 ' is revolved on the vertical line that extends the baseline ' $C$ ' (f) a horizontal line from this point intersects the perspective image of the line ' $a$ ' and detects the perspective image of point ' 3 '.

Plate 18 (Fig. 8) illustrates the solution to the same problem with the 'legitimate construction'. The determination of the $y$ coordinate of the perspective image of ' 3 ' follows the aforementioned steps.

With reference to the $x$ coordinate, Amato acutely considers that, when using a slanting picture plane, the perspective of a point in top view does not overlay its baseline. He therefore suggests drawing a vertical line ' $b$ ' from the point where the projection ray intersects ' $\mathrm{K}$ ' (Fig. 9). In top view, the segment delimited by the main visual axis and the point where ' $b$ ' intersects the visual ray, measures the $x$ coordinate of the perspective image of ' 3 '. ${ }^{13}$

\footnotetext{
13 Per formare il detto Pentagono posto in Prospettiva, si deve prendere la misura, e larghezza... per infino al punto, notato nell'alzata della linea di sopra... nel punto... si formerà una linea retta, che sia parallela alla detta linea della Superficie, e base del Pentagono, per infino a toccare le linee rette, che sono tirate dalli detti punti degli angoli... à terminare nel detto punto dell'occhio... (Amato 1733, p. 51).
} 


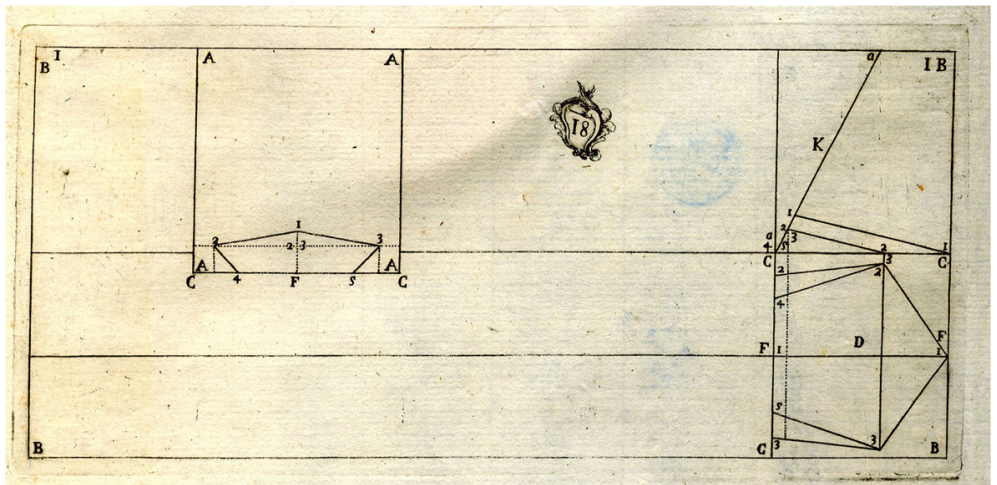

Fig. 8 Nuova Pratica di Prospettiva, plate 18: perspective 'legitimate construction' of a pentagon on a slanting plane

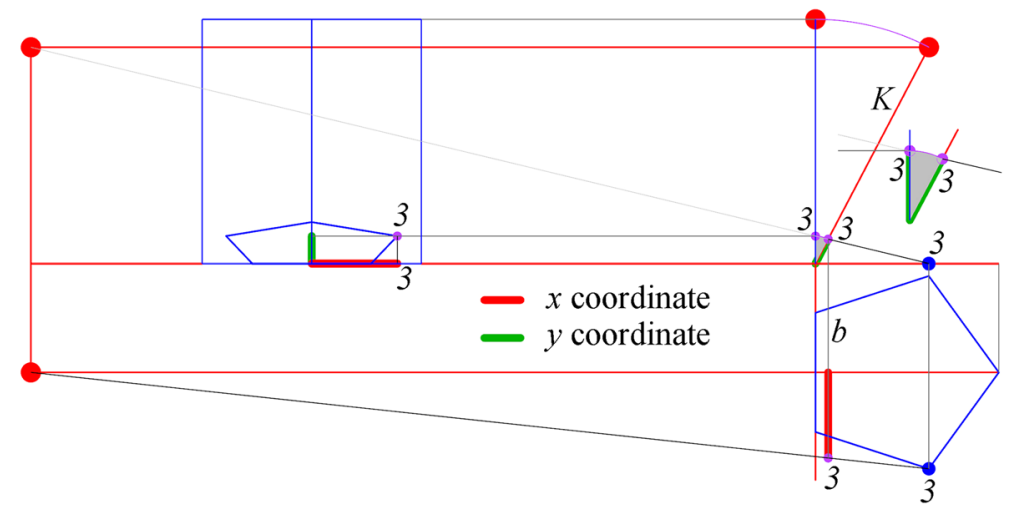

Fig. 9 Geometric scheme from plate 18

Plate 25 illustrates the perspective of a hexagonal prism on a slanting plane. The drawing shows an error, i.e. the perspective image of the vertical edges of the prism are parallel to each other (Fig. 10). It is well known that, when the picture plane is slanting, vertical lines concur to the point where a vertical line from the PoV intersects the picture plane (Fig. 11). The text referred to plate 25 reveals that Amato's statements are correct, and that the error is certainly due to the editor. The exercise in plate 25 is an extension of the method used in plate 18. The proposed scheme (Figs. 12,13) illustrates the text and reveals the accuracy of the suggested process.

\section{Perspective on Cylindrical Surface (Plate 22)}

The perspective on curved surfaces is the outstanding subject in the treatise of Amato. Plate 22 illustrates the perspective of two centered squares on a cylindrical 


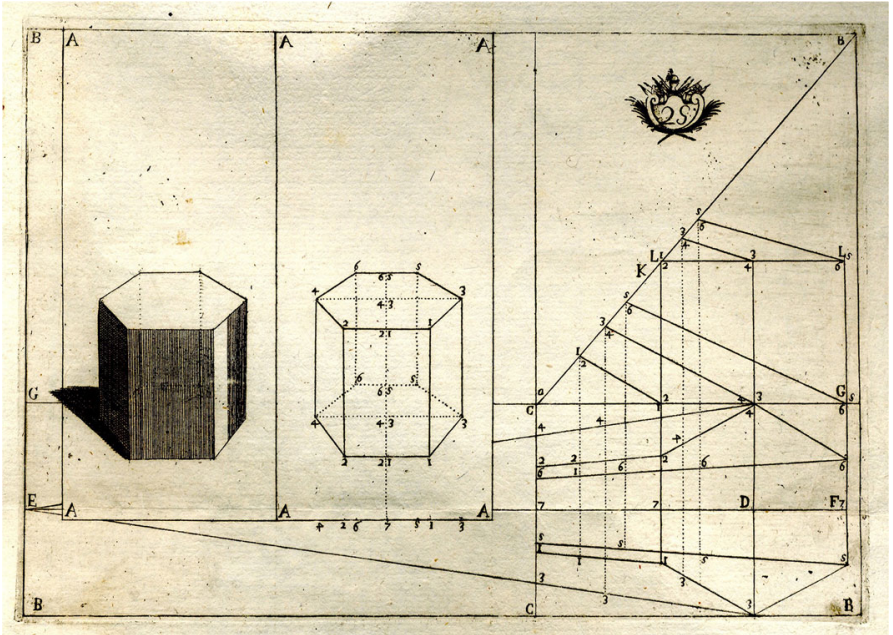

Fig. 10 Nuova Pratica di Prospettiva, plate 25: perspective of a hexagonal prism on a slanting plane

surface; the baseline of the picture surface is half a circle and the width of the Cartone equals its length (Fig. 14). Referring to Archimede, Amato states that the ratio of the length of a circle and the length of its radius is 22/7. To divide the half circle in 22 parts, he therefore suggests dividing the radius in 14 parts. The width of the Cartone equals the sum of the 22 segments. In top view, the $x$ coordinate of the perspective image of a vertex, say ' $n$ ', equals the length of the arc of circle stretching from the main visual axis to the point where the visual ray intersects the baseline of the picture surface (Fig. 15). A vertical line through such point represents, in profile view, the generatrix of the cylinder that meets the vertical plane containing the visual ray. In profile view, the visual ray through ' $n$ ' intersects such line; the segment delimited by this point of intersection and the ground line is the $y$ coordinate of the perspective image of ' $n$ ' (Fig. 16).

Being aware that the perspective images of the sides of the squares will result in ellipses, the author proposes to divide each side into four parts (the author reminds us that more divisions would provide higher accuracy but, at the same time, would make the drawing unclear to uneducated readers). Finally, he states that the sides of the square are the curved lines connecting the perspective images of the division points (see Fig. 16).

\section{A Temporary Conclusion}

Closing the discussion on the treatise of Amato, it is worth mentioning that the Nuova Pratica shows many similarities with the Prospettiva Pratica, an unedited treatise written in Florence a century earlier by Ludovico Cigoli (1559-1613). ${ }^{14}$ The arrangement of the Prospettiva Pratica directly echoes Amato's treatise:

\footnotetext{
14 Rodolfo Profumo published Cigoli's treatise for the first time in 1992. In this article, quotations and images refer to the last edition, published by Filippo Camerota in 2010.
} 
Fig. 11 Three-dimensional representation of the perspective in plate 25

The treatise is composed of two books... The first book deals with subjects preliminary to the study of perspective... and the method used for orthogonal projection in plan and elevation... The second book shows how the same figures... can be drawn in perspective with the aid of three rules. The first rule is the so-called 'legitimate construction' of Filippo Brunelleschi, which concerns... the visual pyramid (and) the central vanishing point. The second rule concerns distance point construction... The third rule... using cords and sights (Camerota 2010, p. 21).

Cigoli uses the 'legitimate construction' to solve three of the problems proposed by Amato: the perspective on two vertical self-intersecting picture planes (Fig. 17), on a plane that is not perpendicular to the axis of view (Fig. 18) and of objects that are placed in front of the picture plane (Fig. 19). The drawings in Fig. 18 show evident similarities to Amato's perspective on a slanting picture plane (see above). Amato does not mention the treatise of Cigoli and we cannot say much more about such similarities. Cigoli mentions the problem of projection on curved surfaces, 


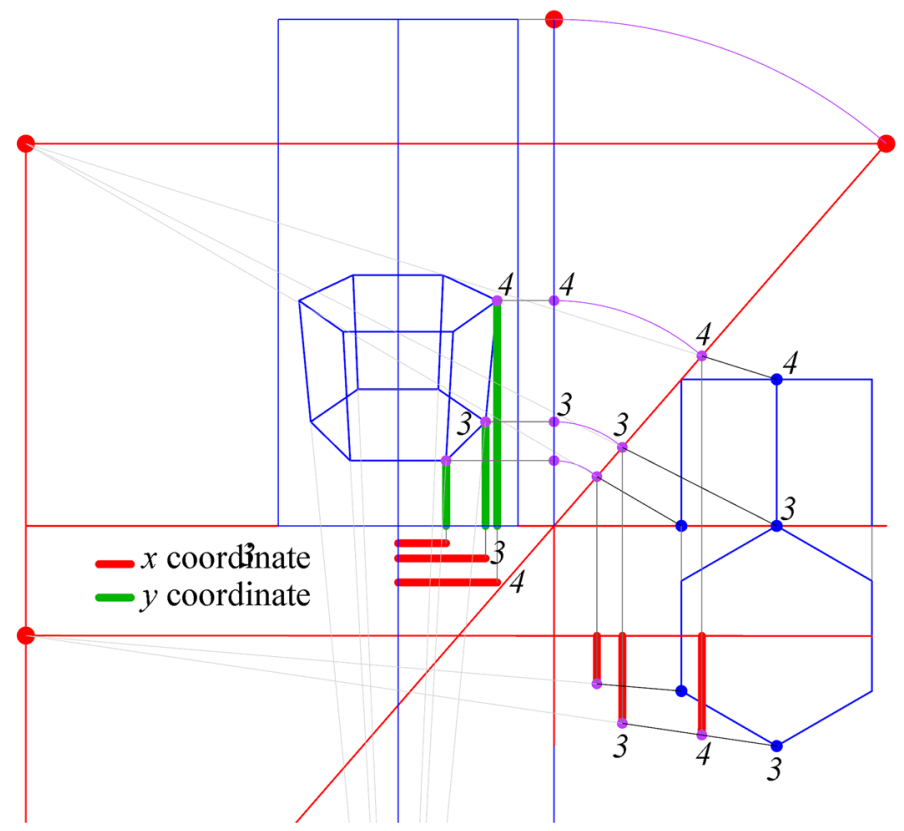

Fig. 12 Geometric scheme from plate 25

with a specific reference to the perspective on vaults (Fig. 20); the discussion is correct, but he finally proposes a 'practical' solution (Fig. 21).

The Nuova Pratica seems to be the first treatise providing an effective 'rule' for the perspective on curved surfaces. As anticipated in the Preface, none of the paintings that Amato realized in his life has come down to us, due to demolitions or restorations. The only trompe l'oeil that can be somewhat referred to the Nuova Pratica, is located inside a Norman church in the historic center of Palermo.

Santa Maria dell'Ammiraglio was built in the twelfth century by Giorgio d'Antiochia, the Chancellor of the Norman King Roger II. The original church had a Greek cross and its entrance door in the western façade opened into a courtyard that was delimited westward by a bell tower. In the sixteenth century, the church was enlarged: the facade and the open courtyard were demolished and a new two-storey pavilion, whose height almost equals the church, substituted for a part of the courtyard. The first level is an extension of the church, whereas the second level is a hall (Fig. 22). The plan of the new building, presumably conditioned by the shape of the courtyard, is almost trapezoidal. Two inscriptions on the pillars at the eastern side of the hall evidence that Mario Cordova and Gaetano Lazzara painted the vault in 1717. In the introduction to the treatise, the editor refers to Lazzara as one Amato's favorite disciples. ${ }^{15}$ Considering that the vault was painted 3 years after the death of Amato, it is possible to argue that Lazzara was still under the influence

15 Sotto la sua disciplina si perfezionarono non pochi soggetti, che riuscirono insigni nell'Architettura, $e$ arte del disegno, frà quali non furon degl'ultimi D. Gaetano Lazzara e D. Carlo Infantolino (Amato 1733). 


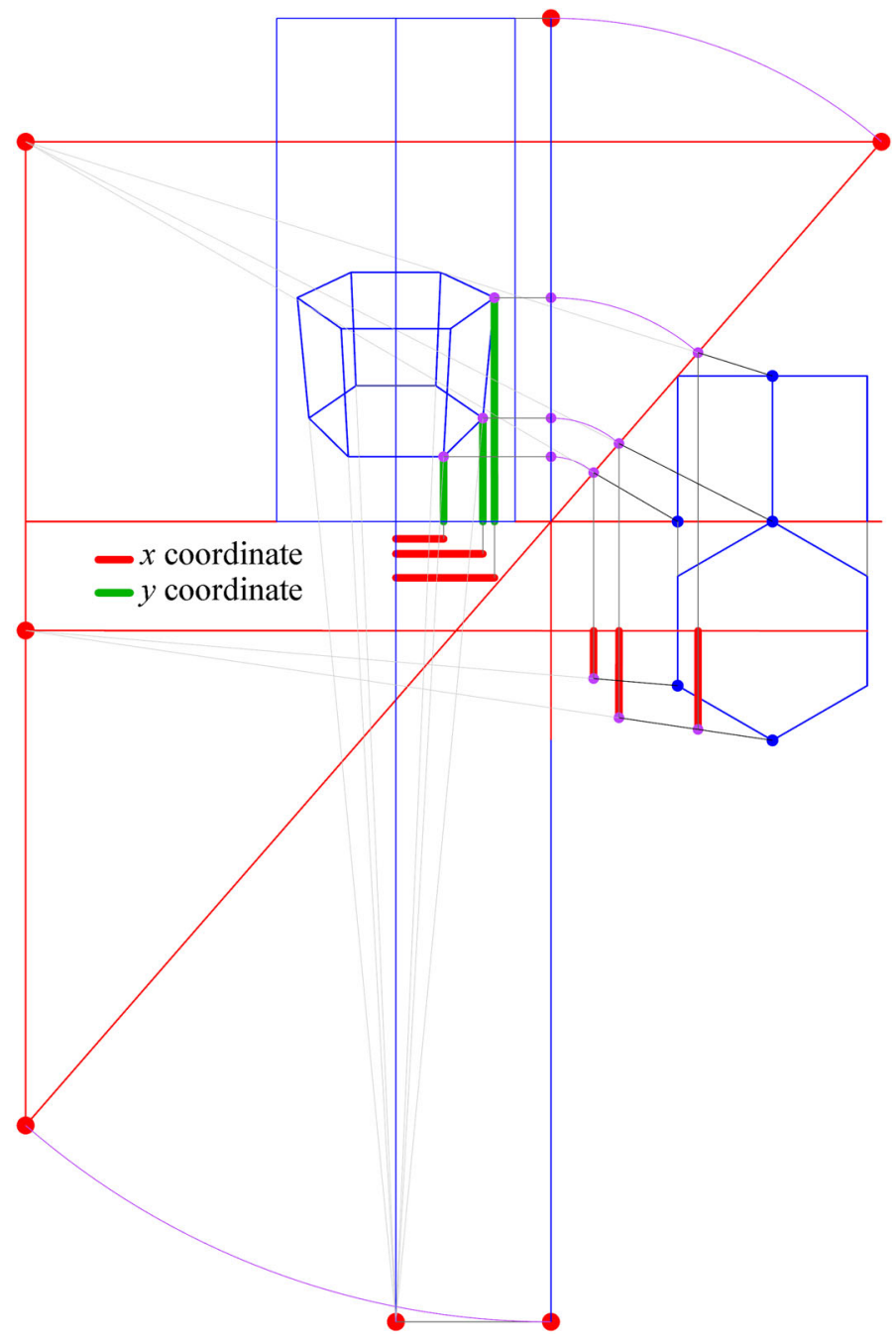

Fig. 13 Geometric scheme from plate 25. Graphical construction of the vanishing point of vertical lines

of his master and that he could have used his perspective method. The lacking historical documentation does not support such a hypothesis, but, if we repute logical induction a correct approach to scientific investigation, the projective analysis of the painted perspective can be a way to verify if a trompe l'oeil using the method of Amato has come down to us.

The combination of 3D surveying techniques and digital representation will support the study; the description of the process will not account many technical details, which are widely discussed in specific literature. In this study, we simply mean to emphasize the opportunities offered by digital tools for the advancement of studies on perspective and, at the same time, propose a repeatable workflow for the 3D analysis of trompe l'oeil on curved surfaces. 


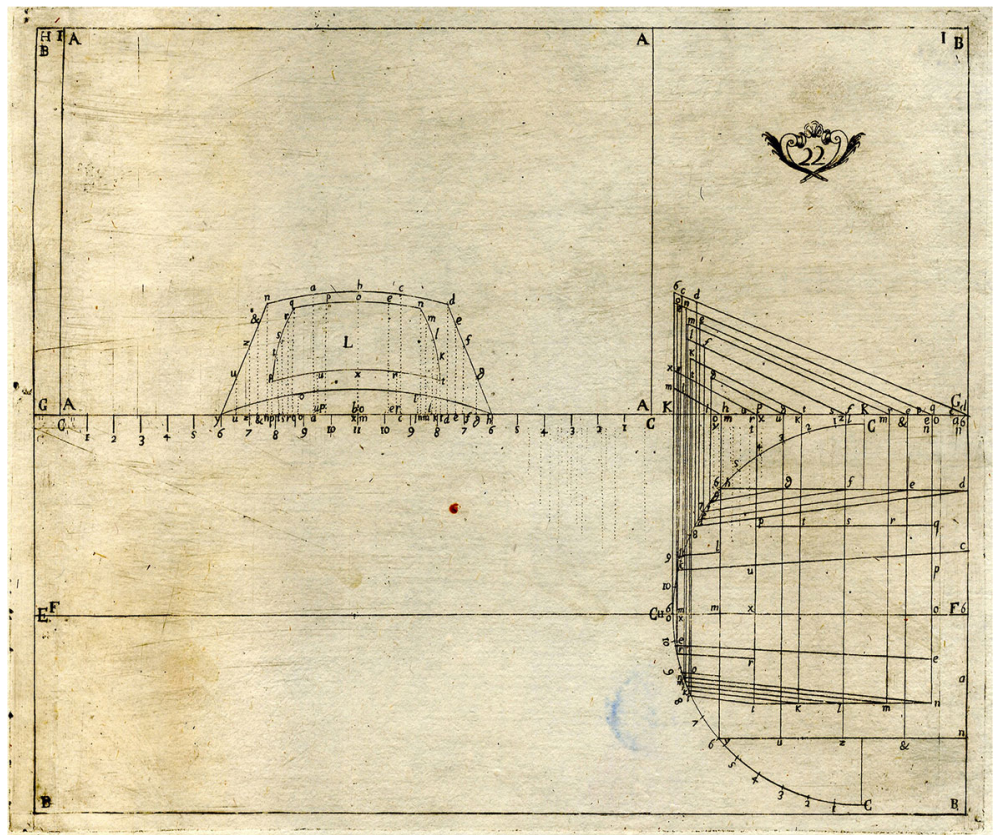

Fig. 14 Nuova Pratica di Prospettiva, plate 22: perspective of two centered squares on a cylindrical surface

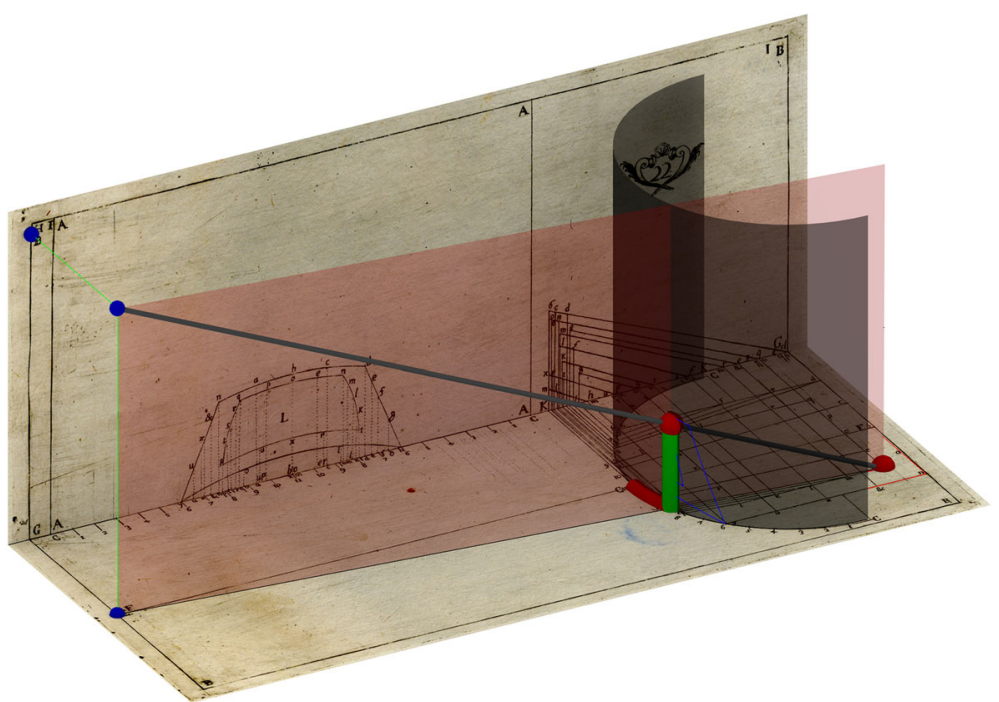

Fig. 15 Three-dimensional representation of plate 22 


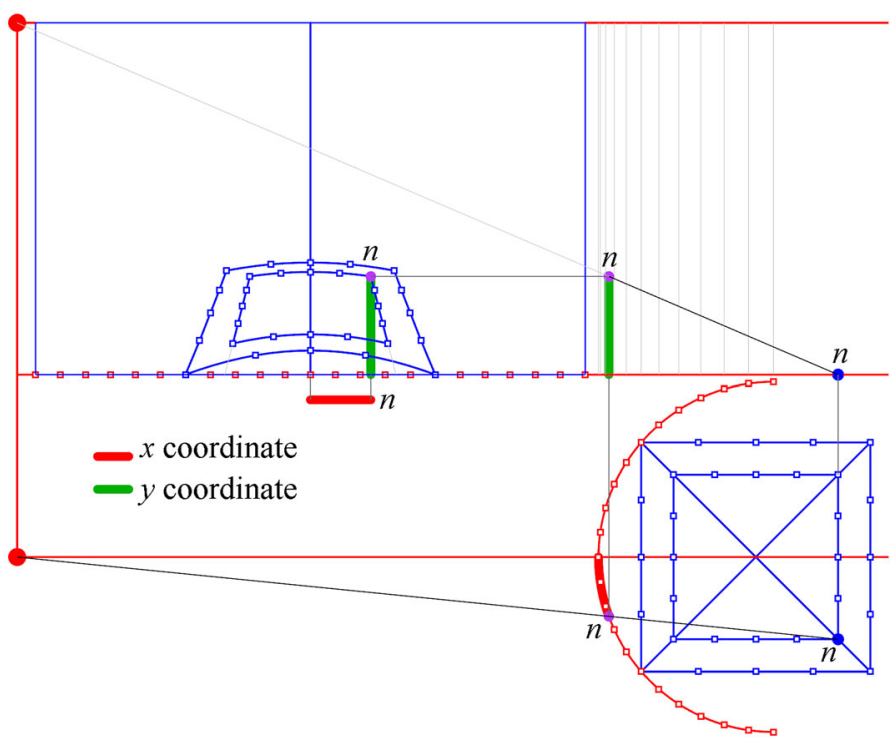

Fig. 16 Geometric scheme from plate 22

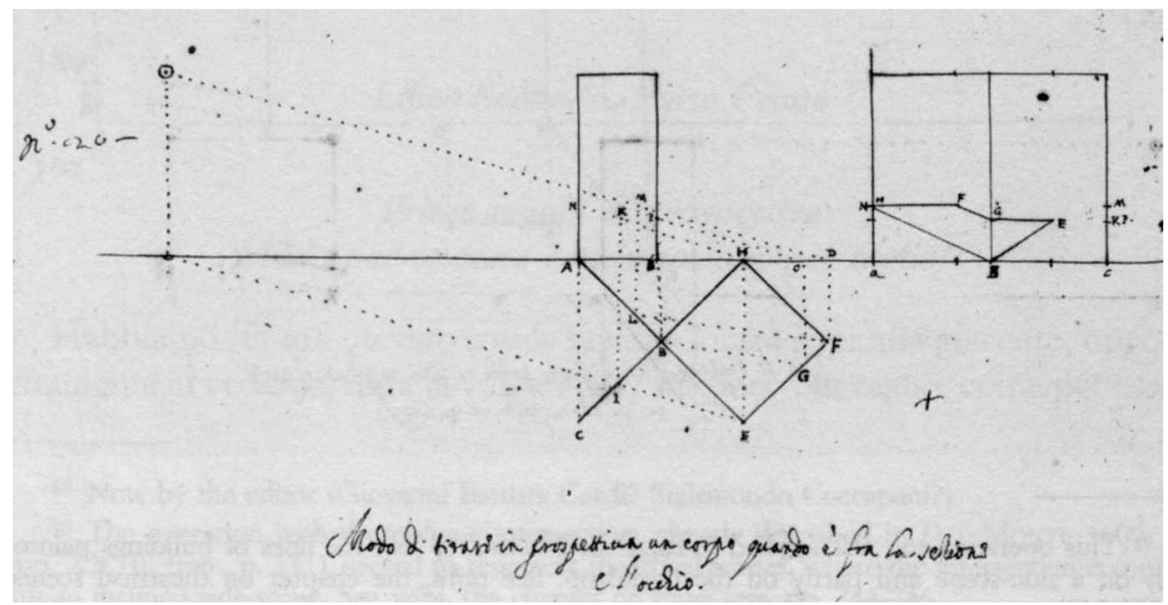

Fig. 17 Cigoli's perspective of a square on two self-intersecting vertical picture planes (Camerota 2010, p. 196) 


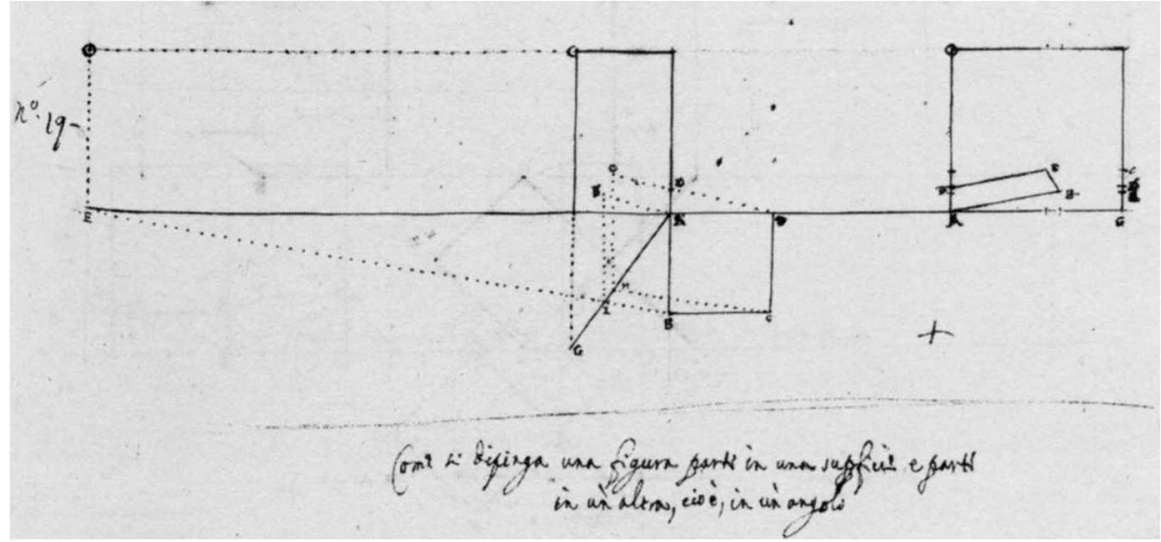

Fig. 18 Cigoli's perspective of a square on a slanting vertical picture plane (Camerota 2010, p. 195)

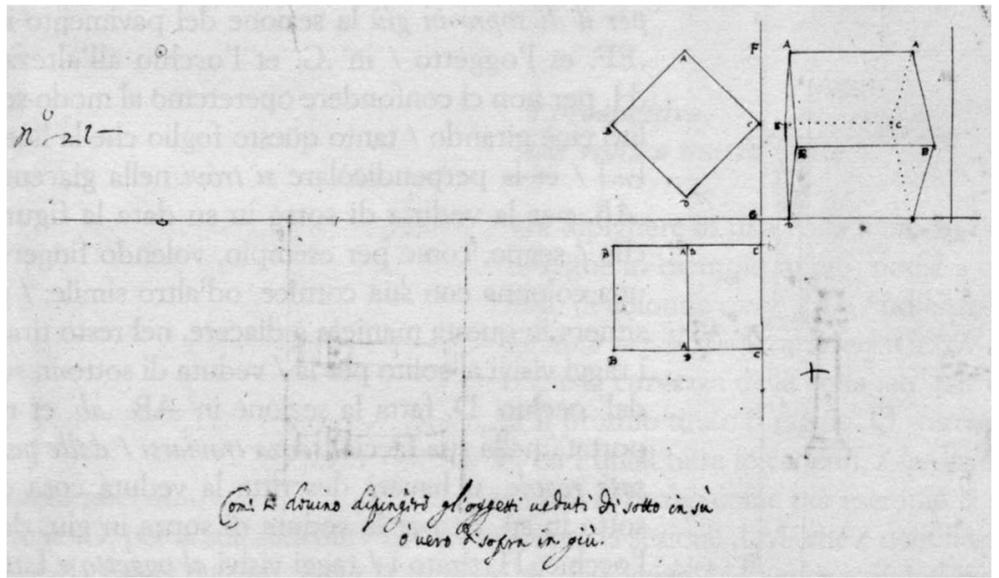

Fig. 19 Cigoli's perspective of a cube placed in front of the picture plane (Camerota 2010, p. 197)

\section{Perspective Analysis of the Painted Vault in Santa Maria dell'Ammiraglio}

Surveying has been performed with laser scanning and photogrammetric methods. A three-dimensional mesh of the hall has been extracted from laser scanning data, whereas photogrammetric processing has provided an accurate texturing of the mesh (Fig. 23). ${ }^{16}$

\footnotetext{
16 A shift-based laser scanner Leica HDS 7000 has provided the detailed point cloud of the vault; point clouds have been registered with the commercial software Leica Cyclone 8.0. 3D Meshes have been extracted from point clouds with the open source software CloudCompare; meshes processing has been performed with the open source software MeshLab. Photogrammetric processing and 3D mesh texturing has been performed with the commercial software Agisoft Photoscan 1.2.2.
} 


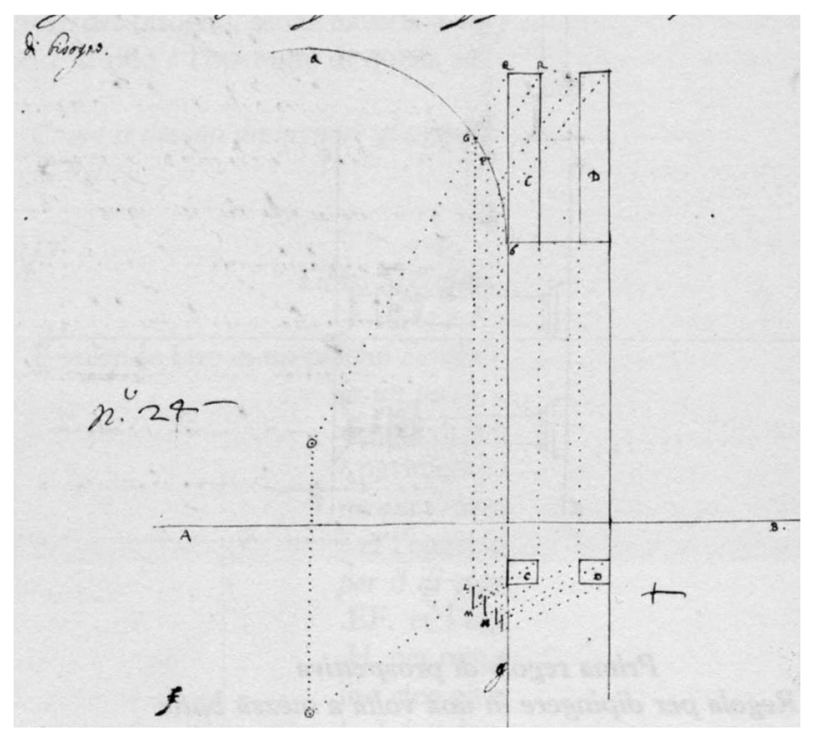

Fig. 20 Cigoli's explanation of perspective drawing on a curved surface (Camerota 2010, p. 200)

Fig. 21 Cigoli's 'practical' method for perspective drawing on curved surfaces (Camerota 2010, p. 303)

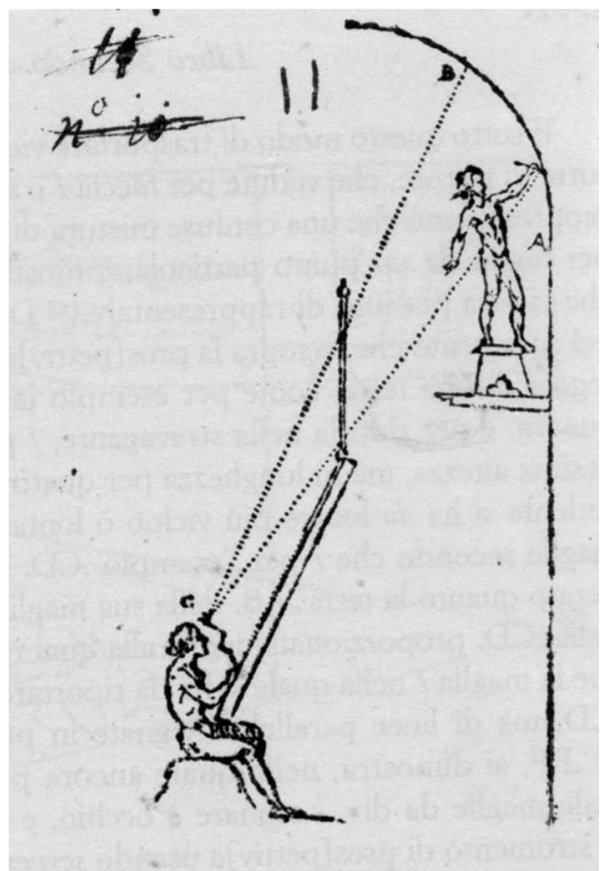



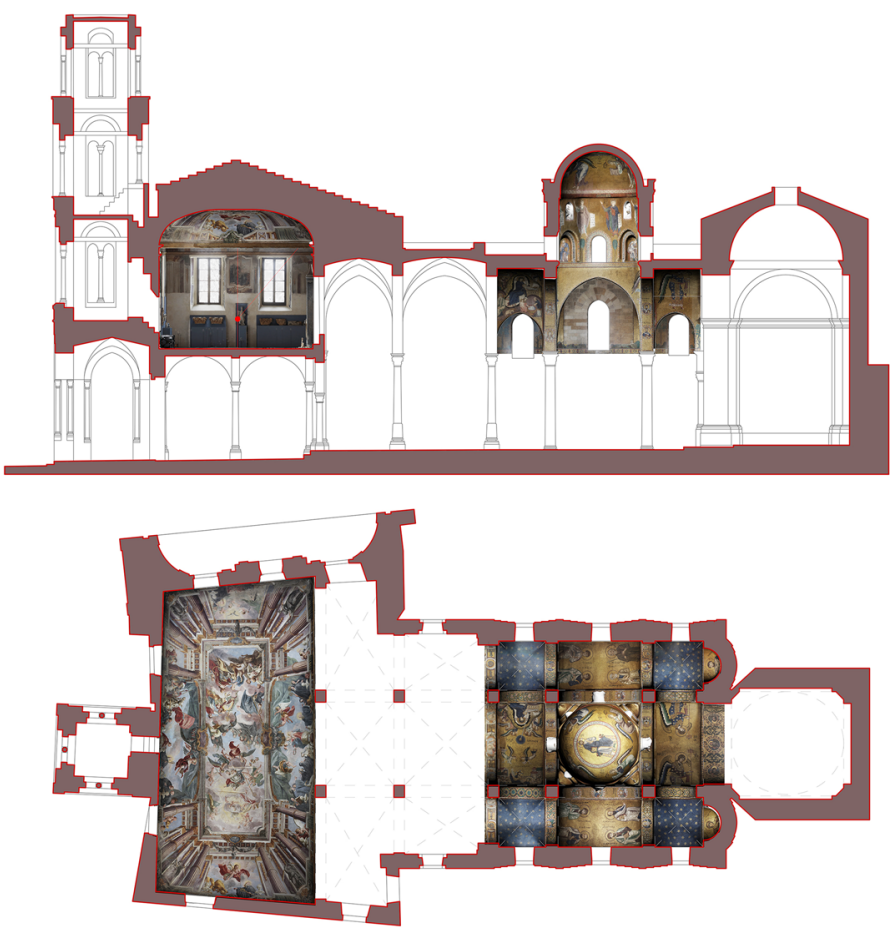

Fig. 22 Plan and section of Santa Maria dell'Ammiraglio with orthophotos of the mosaics of the Norman church and of the painted vault in the hall
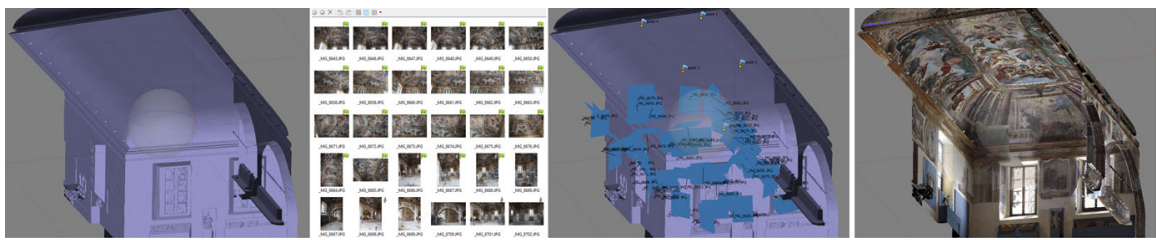

Fig. 23 From left to right view of the mesh from laser scanning data; photos of the hall; photos alignment and referencing; mesh texturing

CAD software allows today the visualization and inspection of $3 \mathrm{D}$ texturized meshes ${ }^{17}$ this means that plane sections can be easily extracted (Fig. 24) and that dimensional and geometrical inspections constantly refer to the 3D model. Furthermore, orthographic views of the textured mesh provide orthophotos of the surveyed surfaces (Fig. 25).

To detect relationships between paintings and the real shape of surfaces, textures can be temporarily disabled: the visualization of the vault, with textures disabled, shows some creases aligned with the cornice above the columns (Fig. 26). It is

\footnotetext{
17 CAD processing has been performed with the commercial software Rhinoceros 5.0.
} 
Fig. 24 Sections extracted from the 3D mesh
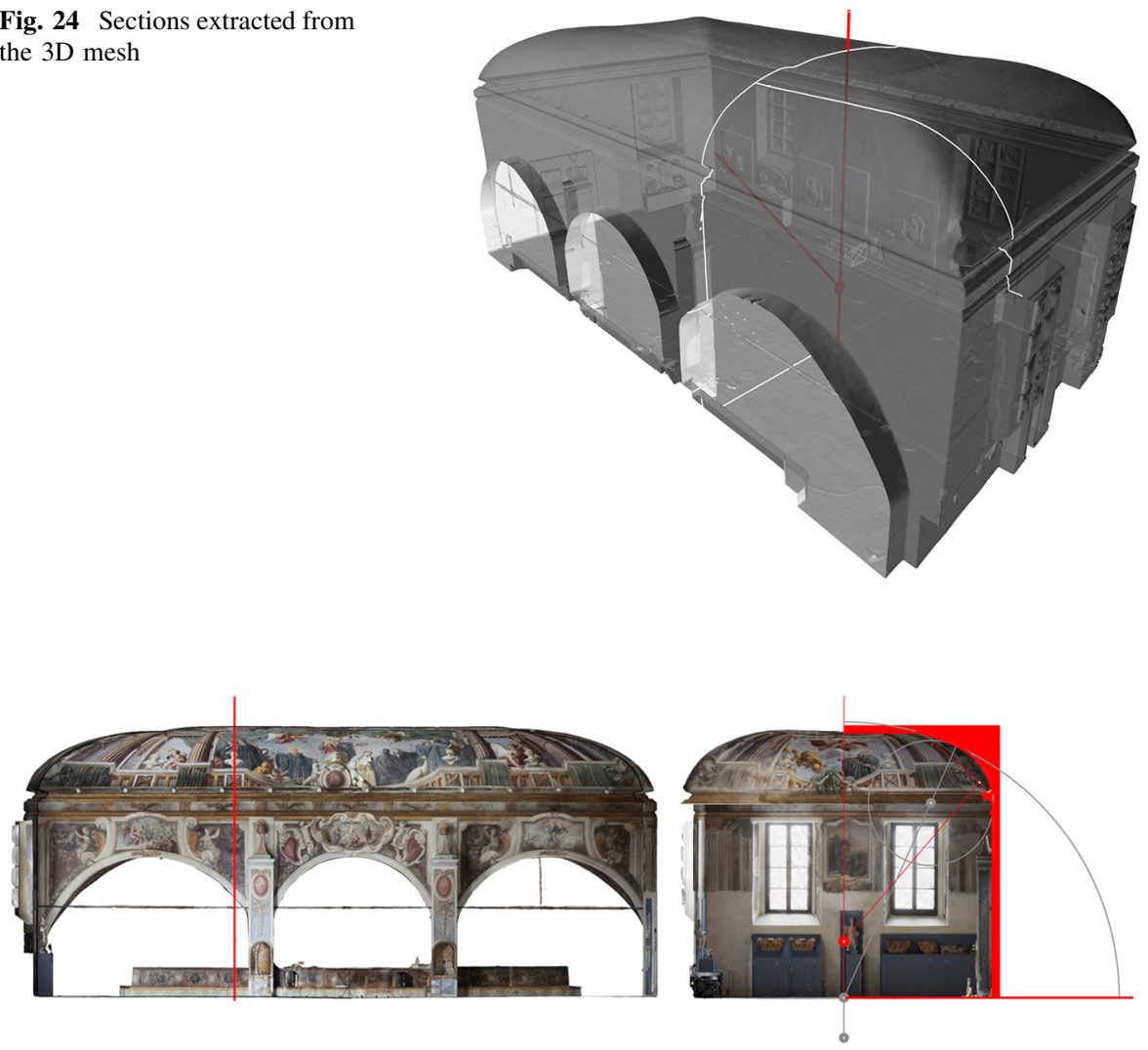

Fig. 25 Orthophotos of the longitudinal and transverse section of the hall

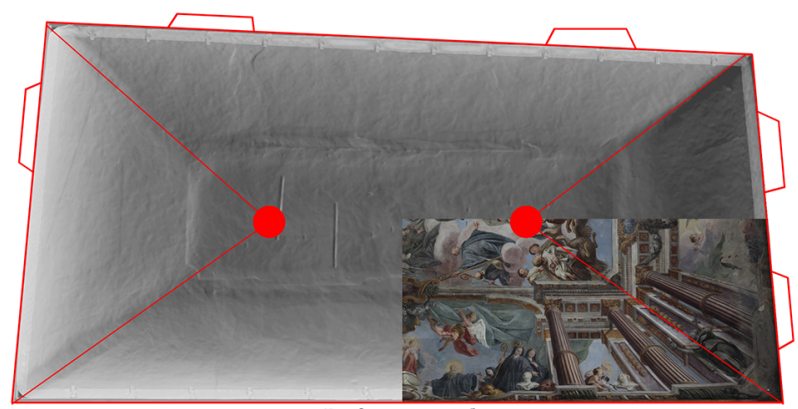

Reference side

Fig. 26 Visualization of the mesh with and without texture 
therefore evident that plaster works on the vault were realized according to the design of the trompe l'oeil.

\section{Geometrical and Perspective Analysis}

The hall is trapezoidal and is covered by a pavilion vault (see Fig. 26); the usual layout of a pavilion vault assumes the room has a rectangular shape and that cylindrical surfaces, having horizontal generatrices, delimit a flat rectangular shape at the top. If builders had followed the usual layout, the flat surface at the top would have reproduced the irregularities of the plan. A blank vault could not cover a hall inside one of the most important churches of the town; we can therefore argue that the plan shape of the vault was designed to fit, from the beginning, the layout of the trompe l'oeil. The painters probably wanted an almost rectangular area at the top of the vault and thus the border barrel vaults were shaped in different ways, to fill the irregular areas from the walls to the flat rectangular area at the top.

The inspection of the plan puts into evidence that the diagonals of the pavilion vault, connecting its corners to their counterparts in the flat rectangle at the top, are not the bisecting lines of the corner angles of the trapezoid. The longer sides of the flat rectangle at the top are parallel to one of the longer sides of the hall, which becomes therefore the 'reference side' (see Fig. 26). We have assumed that the vertical profile of the barrel vault has been drawn on a plane perpendicular to such line (see Fig. 25), whereas the profiles of the remaining barrel vaults constantly change to fit the irregularities of the hall. The diagonals of the vault match the perspective lines concurring to two distinct vanishing points (see Fig. 26), according to a scheme effectively illustrated in a well-known plate from the treatise of Palomino (Fig. 27).

The orthographic top view of the painted vault shows that the lines concurring to the vanishing points appear straight (see Fig. 26). If we consider the projection of a prism on a vault, we notice that the planes projecting the horizontal edges are parallel to the axis of the barrel vault and intersect the cylinder in straight horizontal lines (Fig. 28a); the elliptical sections produced by the planes projecting the vertical edges, appear straight in orthographic projection (Fig. 28b); the elliptical sections produced by the planes that project the horizontal edges perpendicular to the axis of the barrel, appear into ellipses in orthographic projection (Fig. 28c). In the treatise of Amato, no plate refers explicitly to the projection on a vault; a variation of the scheme referred to plate 22 (see Fig. 16) is therefore proposed to simulate the projection of a prism on a barrel vault (Fig. 29).

The following step addresses the reconstruction of the painted scene. The restitution of the plan of the painted architecture uses the orthographic projection of the vault (Fig. 30a). The elevation of the architectural scene has been restituted using projection planes passing through the horizontal lines in the perspective drawing. The restitution has proved that proportions in elevation, and the ratio of plan to elevation as well, almost matches the drawings of the 'composite' order from the treatise of Vignola (Fig. 30b). For the restitution of the elevation, the point of view has been positioned on the vertical axis through the vanishing point, $1.50 \mathrm{~m}$ above the floor of the hall (Fig. 31); the elevation of the point of view is obviously 


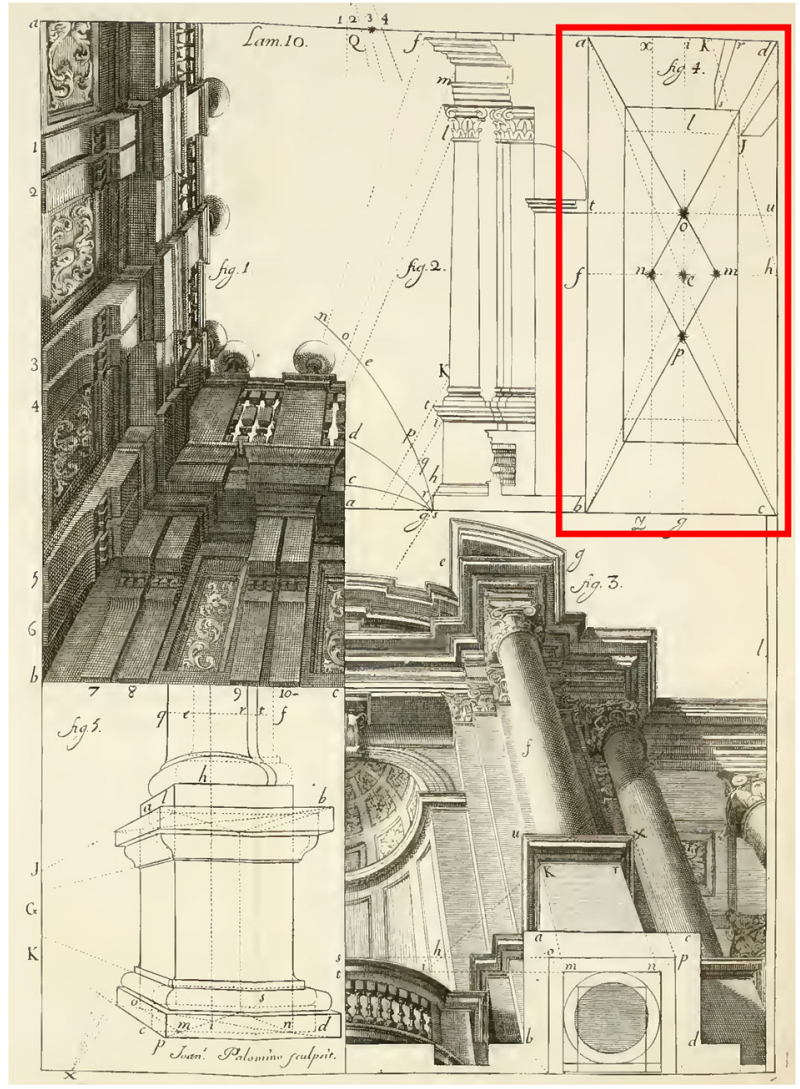

Fig. 27 Plate 10 from the El museo pictorico... of Palomino Velasco, illustrating the perspective on a pavilion vault (Palomino 1797, p. 380)

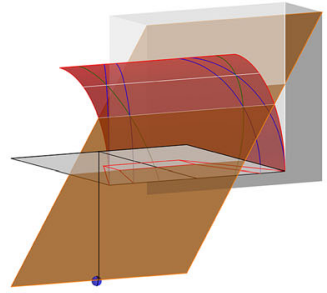

$\mathbf{a}$

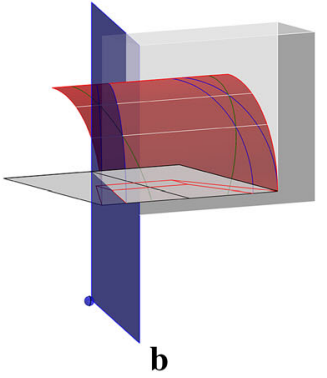

b

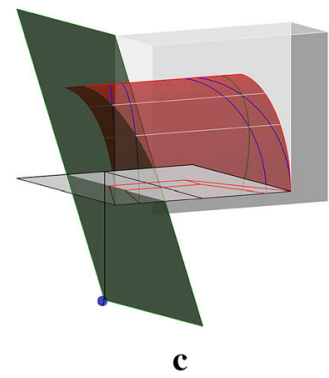

c

Fig. 28 Planes projecting the edges of a prism on a cylindrical vault

tentative; a higher elevation would appear odd if we consider the average height of a human being; a smaller elevation would have produced a giant architectural scene. The view of the 3D textured mesh from the chosen point of view supports the 


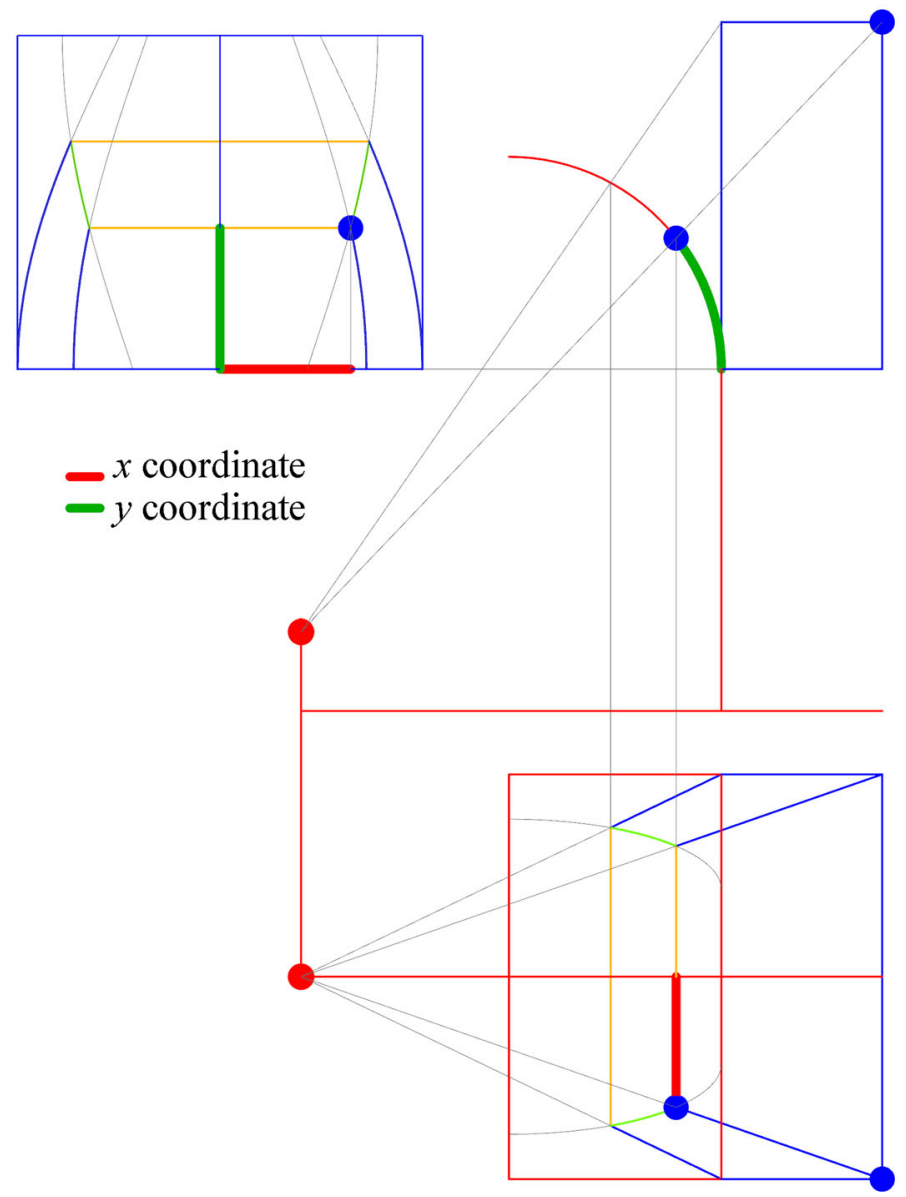

Fig. 29 Scheme of perspective on a vault according to Amato's method

tentative positioning, showing that the lines concurring to the vanishing points appear straight (Fig. 32).

The correspondence between the restitution model and the perspective drawing has been validated assigning a transparency value to the textured 3D mesh (Fig. 33). The most relevant errors appear in the line of the balustrade supporting the columns, and in the alignment of the columns and their bases; both errors appear in the lower end of the barrel vaults, and are probably due to the intention of showing elements that correct perspective projection would have occluded. The lower area of the painting recurs almost identically on all sides of the hall; it is therefore reasonable to suppose that, in order to conceal the deformations due to the changing shape of the barrel vaults, the painters chose to deform the shafts of the columns and leave the horizontal lower strip with the balustrade unchanged. 


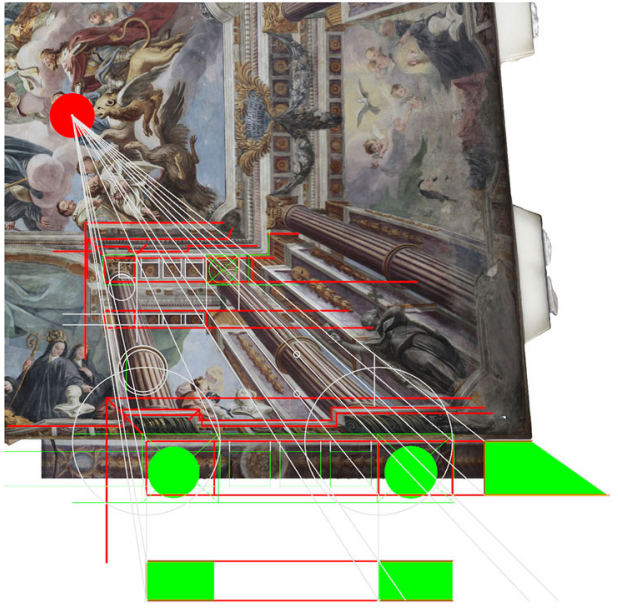

$\mathbf{a}$

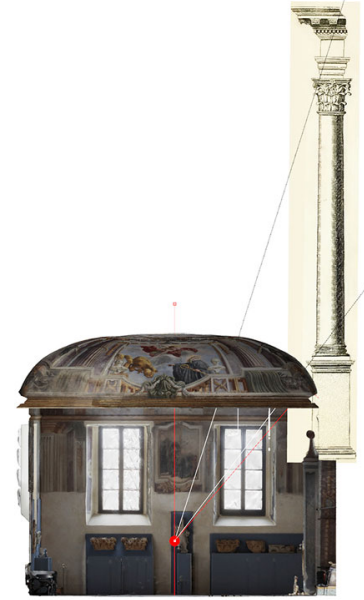

b

Fig. 30 Plan and elevation of the restituted architectural scene

Fig. 31 Perspective view of the 3D textured mesh and position of the point of view

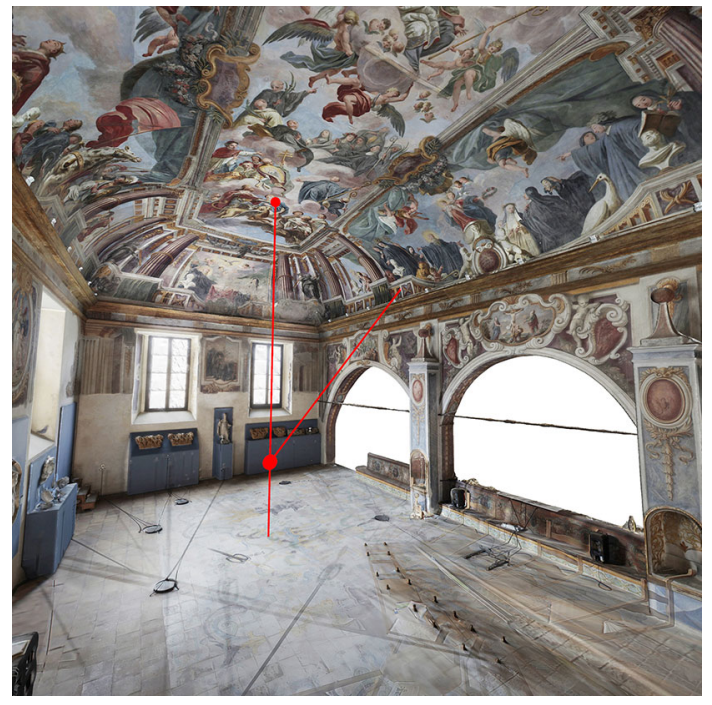

\section{Unexpected Results}

Even if restitution had produced good results, an important question had remained unanswered: how did the painters design the trompe l'oeil? Did they start imagining an architectural scene or did they start from the shape of the plan? Some previous unpublished research has yielded evidence that axonometric drawings in mosaics 
Fig. 32 Perspective view of the 3D textured mesh from the point of view
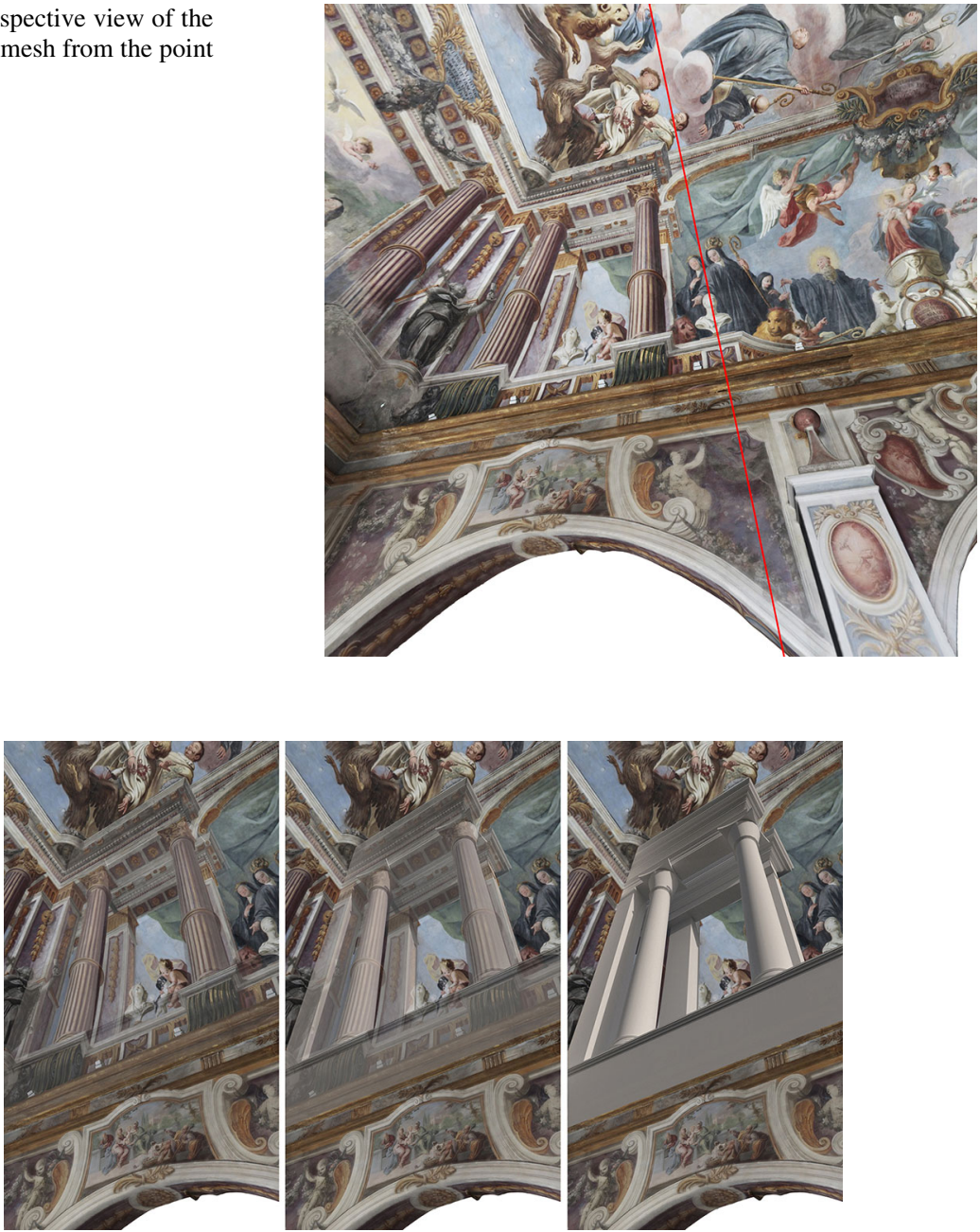

Fig. 33 Perspective view of the painting and the 3D model of the architectural scene; transparencies allow the detection of congruities and deviations

hid a geometrical pattern. A tentative geometrical analysis of the painted vault has been therefore performed.

The geometric analysis, carried out on the orthographic projection of the vault, has revealed that the 'project' of the painting was probably designed using a pattern based on straight triangles whose sides are in ratio 1 to $\sqrt{2}$. The hypothetical geometrical construction of the painting is proposed in six steps (Fig. 34): the reference horizontal line is divided in two equal segments named $a$, transverse and longitudinal axes are drawn (Step 1); a segment, whose length is $a / \sqrt{2}$, is reported on the transverse axis with a well-known geometrical construction (Step 2); the line connecting the point on the transverse axis and the corner of the hall, intersects the 


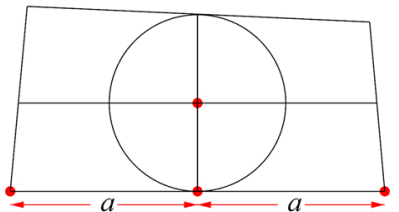

1)

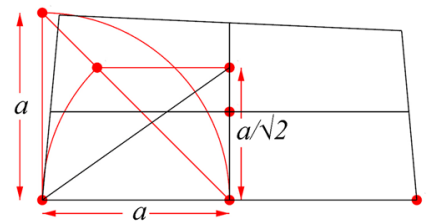

2)

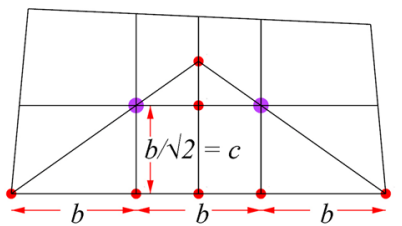

3)

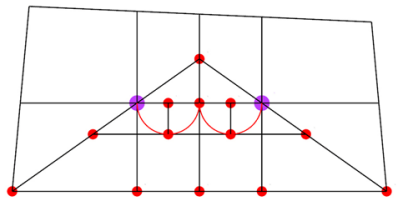

4)

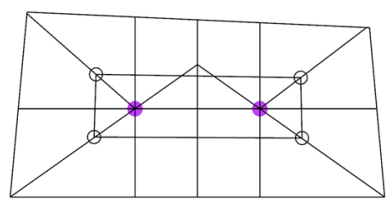

5)

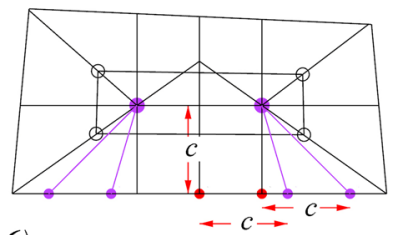

6)

Fig. 34 Geometrical design of the trompe l'oeil

longitudinal axis in the left vanishing point; the right one is mirrored along the transverse axis; the vertical lines through the vanishing points divide the reference line in three equal segments named $b$, whose ratio to the half of the transverse axis is b/ $\sqrt{2}$ (Step 3); a further horizontal line, whose distance from the longitudinal axis equals the half of the distance from the vanishing point to the transverse axis, is traced; such line matches the lower edge of the rectangle delimiting the flat area of the pavilion vault (Step 4); the general scheme of the painting (and of the vault as well) is traced (Step 5); the half of the transverse axis is reported on the reference line and two points are detected (Step 6); the perspective lines through these points are the axes of the columns in the painting (Fig. 35).

What geometrical analysis suggests is that the Cartone presumably filled a small trapezoidal area of the barrel vault, where most architectural elements are placed; this area is delimited by: the reference side of the hall, the projection line orthogonal to it, the side of the top area of the vault; the line from the vanishing point to the corner of the hall. Properly copied and rotated, the Cartone entirely fills the barrel vaults on the short sides of the hall, whereas in the long sides a small cornice, terminated by two halves of an arch, connects the scenes in the Cartoni. The ends of the cornices depicted in the Cartoni are close to the projection plane perpendicular to the reference side, and thus they appear almost straight in orthogonal projection.

Digital representation made possible the visualization of the Cartone supposedly drawn by painters; thanks to specific tools, which allow unwrapping of a 


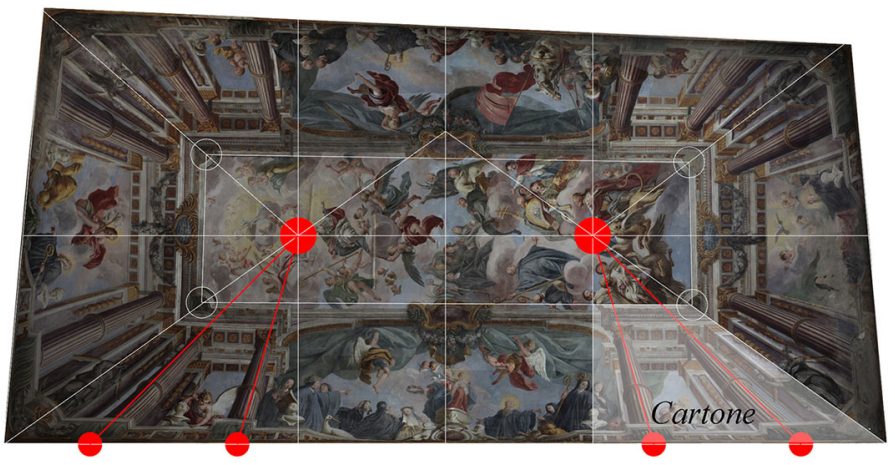

Fig. 35 Geometric scheme on the orthophoto of the vault and area filled by the Cartone
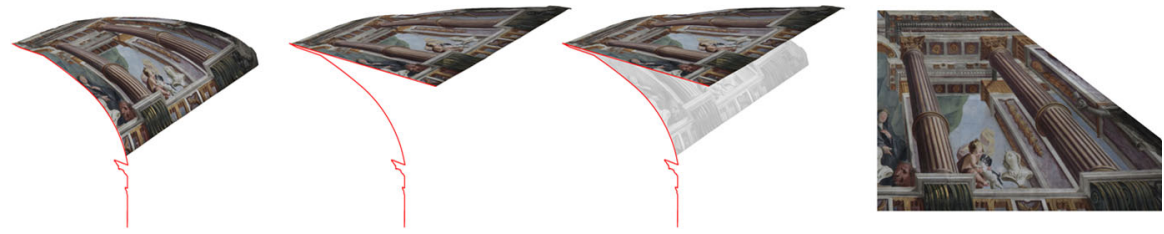

Fig. 36 3D mesh unwrapping and restitution of the Cartone

developable surface along a line ${ }^{18}$ it is possible to visualize the hypothetical Cartone of the studied vault (Fig. 36).

\section{Conclusions}

In this study an interesting and almost unknown treatise on perspective has been discussed, both to make justice of his qualities and to offer the community of scholars a tool for further investigations. The description of the plates illustrating the text has highlighted the skills of the author both in perspective theory and practice; the main points of interests are the projection on slanting planes and on cylindrical surfaces, which exceeds the coeval 'practical' treatises on perspective. The secondary purpose of this study is to put into evidence the contribution that digital tools offer today to the studies on trompe l'oeil; a repeatable method, integrating 3D surveying and digital representation tools, has been tested on the perspective restitution of an architectural scene painted on a vault at the start of the eighteenth century. The 3D textured model allowed comparison between the painting and the real shape of the vault, and effectively supported the restitution of a specific area of the vault. The model appears proportioned in plan and elevation, but its height is oversized (Fig. 37). The disproportion, which would be unacceptable in real architecture, can be accepted in painted architecture, because the geometry of the surfaces to be painted often forced painters to oversize their scenes to match the

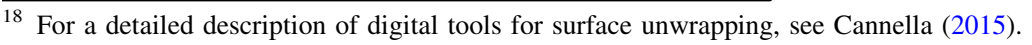


Fig. 37 Transverse section of the hall and of the 3D model of the architectural scene

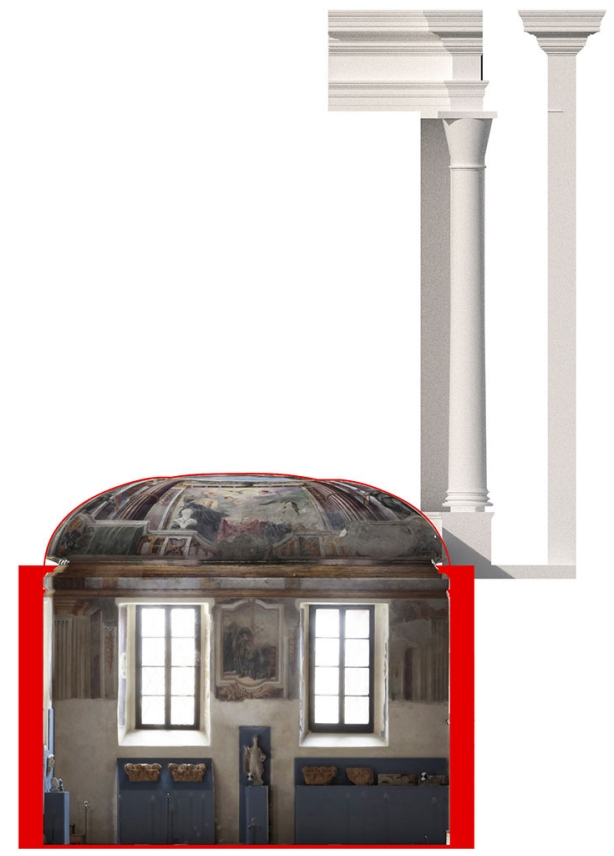

lines or the corners of the surface. ${ }^{19}$ Finally, the orthophoto view of the vault has supported a study on the design of the vault, which highlighted a rigorous geometric scheme underlying the painting. The scheme has allowed a deeper understanding of the trompe l'oeil and has led to the identification of the Cartone used by the painters. Further tools for digital representation allowed unwrapping the area of the $3 \mathrm{D}$ textured mesh corresponding to the Cartone and thus led to its tentative reconstruction.

The studies on trompe l'oeils in Sicily ${ }^{20}$ are still at the beginning and there is much work to do, but probably many more famous and gorgeous trompe l'oeil on curved surfaces are still waiting for an up-to-date study using digital tools.

\section{References}

Amato, Paolo. 1733. La nuova pratica di Prospettiva. Biblioteca Regionale Siciliana, Rari Sic. 627. Camerota, F. 2010. Linear Perspective in the Age of Galileo. Ludovico Cigoli's Prospettiva Pratica. Firenze: Leo S. Olschki Editore.

\footnotetext{
19 "The outcome of the restitution of the virtual architecture reveals many incongruities in the architectural composition, whereas it seems evident that scenographical demands have prevailed... the project of such virtual architecture is not aimed to represent a specific scene, but is oriented to the creation of a scenographical context capable of expressing the cultural content requested by the patron" (Carlevaris 1999, pp. 140 and 147).

${ }^{20}$ A history of trompe l'oeil in Sicily in the eighteenth century is outlined in Piazza (2006) and in Zalapì (2006)
} 
Cannella, M. 2015. Sviluppo e rappresentazione digitale di superfici architettoniche complesse per la documentazione e il restauro. Disegnare con, 8 (14): 3.2-3.8.

Carlevaris, Laura. 1999. La geometria della costruzione pittorica: dallo schema compositivo allo schema prospettico. In: La costruzione dell'architettura illusoria, eds. Maurizio De Luca et al., 121-152.

D'Accolti, Pietro. 1625. Lo inganno degli occhi. Prospettiva pratica. https://archive.org/details/ loingannodeglocc00acco (accessed 21 September 2015).

Della Francesca, Piero. 1984. De prospectiva pingendi, (1475?). Ed. Giusta Nicco-Fasola. Firenze: Le Lettere.

Di Marzio, Daniele. 1999. La Sala Clementina in Vaticano. Procedimento per la costruzione della prospettiva su superfici curve: ipotesi teorica e verifica sperimentale. In: La costruzione dell'architettura illusoria, eds. Maurizio De Luca et al., 153-177.

Milliet Deschales, Claudio Francesco. 1674. Cursus seu Mundus Mathematicus. Tomo secundo. Tractatus XIX. Perspectiva. Seu de radio directo. https://books.google.it/books/about/Cursus_seu_Mundus_ mathematicus.html?id=Z_MuAAAAQAAJ\&redir_esc=y. (Accessed 15 September 2015).

Nicéron, Jean François. 1652. La Perspective curieuse. https://archive.org/details/bub_gb_7xMOAAAA QAAJ (accessed 21 September 2015).

Palomino Velasco, Antonio, 1797. El museo pictorico y escala optica, Tomo Segundo. https://archive.org/ details/elmuseopictorico23palo (accessed 2 October 2015).

Piazza, Stefano. 2006. Fonti e modelli dell'architettura dipinta nella Sicilia del Settecento. In: Realtà $e$ illusione nell'architettura dipinta, eds. Fauzia Farneti and Deanna Lenzi, 427-438. Firenze: Alinea.

Pozzo, Andrea. 1693. Perspectiva pictorum et Architectorum. https://archive.org/details/gri_ 33125008639367 (accessed 20 September 2015).

Ruggeri Tricoli, M.G. 1983. Paolo Amato. La corona e il serpente. Palermo: Epos.

Vagnetti, L. 1979. De naturali et artificiali perspectiva. Firenze: Libreria Editrice Fiorentina.

Zalapì, Angheli. 2006. Per una storia del quadraturismo in Sicilia: profilo di alcuni protagonisti. In: Realtà $e$ illusione nell'architettura dipinta, eds. Fauzia Farneti and Deanna Lenzi, 451-458. Firenze: Alinea.

Fabrizio Agnello was born in 1965 and graduated in Architecture at the University of Palermo in 1992, in 1995 he gets a Ph.D. in Architecture Representation and Surveying. In 1999 he starts working as a researcher at the University of Palermo and in 2015 he is appointed Associate Professor in Drawing at the Department of Architecture. The research activity, developed through individual studies and in the tutorship of Ph.D. and graduation theses, is mainly focused on the use of surveying and digital representation techniques for the documentation and the geometric analysis of historic monuments and works of art. 